Chemical Constraints on the Origin of the Frailes Volcanic Complex in the Central \author{
Andean Altiplano Plateau, Bolivia \\ Honors Thesis \\ Presented to the College of Agriculture and Life Sciences, \\ Physical Sciences Honors Committee \\ of Cornell University \\ in Partial Fulfillment of the Requirements for the Research Honors Program \\ for the Degree of Bachelor of Science
}

by

Christoper Brenhin Keller

April 2010

Suzanne Mahlburg Kay 


\section{Chemical Constraints on the Origin of the Frailes Volcanic Complex in the Central Andean Altiplano Plateau, Bolivia}

\section{Abstract}

The Frailes volcanic complex of the Bolivian Altiplano plateau is the largest and most prominent ignimbrite of the Andean Central Volcanic Zone. With $2000 \mathrm{~km}^{3}$ of exposed volcanic deposits dating from $25 \mathrm{Ma}$ to the present, the complex provides insight into the processes of large-volume silicic melt formation in a back-arc setting. However, the voluminous 0-10 Ma main body of the Frailes complex remains poorly studied, as the majority of the literature focuses on a small region of 12-14 Ma Sn-Ag mineralization at Cerro Rico - the world's largest silver deposit. Here, we present geochemical analyses of 25 representative samples from our fieldwork on the Frailes ignimbrite. Whole-rock major element analysis by X-ray fluorescence spectroscopy showed the $\sim 7$ Ma samples to be highly peraluminous, potassic $(>5 \% \mathrm{~K} 2 \mathrm{O})$ andesitic to rhyodacitic welded volcanic tuffs with an Al-rich, chemically reduced mineral assemblage including biotite, calcic feldspar, magmatic cordierite, and ilmenite. Trace element analysis by instrumental neutron activation revealed steep rare earth patterns with $\mathrm{Sm} / \mathrm{Yb}>5.0$, requiring the presence of garnet in a deep-crustal, high-pressure restitic assemblage. In contrast, the presence of cordierite indicates crystallization at low pressure $(<450 \mathrm{MPa})$, at depths of less than $14 \mathrm{~km}$. In addition, geochemical analyses combined with the geocronological work of Barke et al. (2007) support a recent ( $\sim 2 \mathrm{Ma})$ age for the ignimbrites of the main Frailes Meseta. These ignimbrites are consequently best explained by mixing of a mantlederived melt with a reduced, lower crustal component at great depths to produce hybrid 
magmas that ascended and evolved to form shallow crustal $(<14 \mathrm{~km})$ magma bodies before erupting in catastrophic, caldera-forming events at $\sim 2$ Ma.

\section{Introduction}

The $2000 \mathrm{~km}^{3}$ (Schneider, 1985) of andesitic to rhyodacitic ignimbrites contained in the Miocene-age Frailes complex provide a key window into the processes of largevolume silicic-to-intermediate melt production in a back-arc setting. Situated in the high Altiplano plateau of the central Andes (Figure 1) above $\sim 65 \mathrm{~km}$ thick crust (Beck et al., 1996), the Frailes complex sits on the edge of one of the largest volcanic provinces on earth: the Altiplano-Puna Volcanic Zone (see e.g. Kay and Coira, 2009), which has erupted at least $12000 \mathrm{~km}^{3}$ of intermediate to silicic magma in the last $10 \mathrm{Ma}$ alone (DeSilva and Gosnold, 2007; Kay et al., submitted). As seen in Figure 2, the Frailes complex is one of the largest of all of the Altiplano-Puna ignimbrites, with approximately 2000 cubic kilometers of 0-15 Ma ignimbrite flows exposed over an area of more than $8500 \mathrm{~km}^{2}$ (Schneider, 1985). Despite the prominence of the Frailes complex among Andean ignimbrites, there has been little geochemical study of the Frailes volcanics less than $12 \mathrm{Ma}$ in age; with the exception of Jimenez et al. (1997) and Luedke et al (1997), existing work in the area has focused primarily on the associated metallogenic ore deposits (e.g. Schneider, 1985; Rice et al., 2005) or on the wider tectonics of the region (e.g. Kennan et al., 1995; Barke, et al., 2007). Presented here are the results of new mineral and whole-rock major and trace element analysis of 25 samples from the Frailes complex as determined by electron probe microanalysis, neutron activation analysis, X-ray fluorescence spectroscopy and optical microscopy. These analyses complement existing chemical data from the work of Schneider (1985), Jimenez 

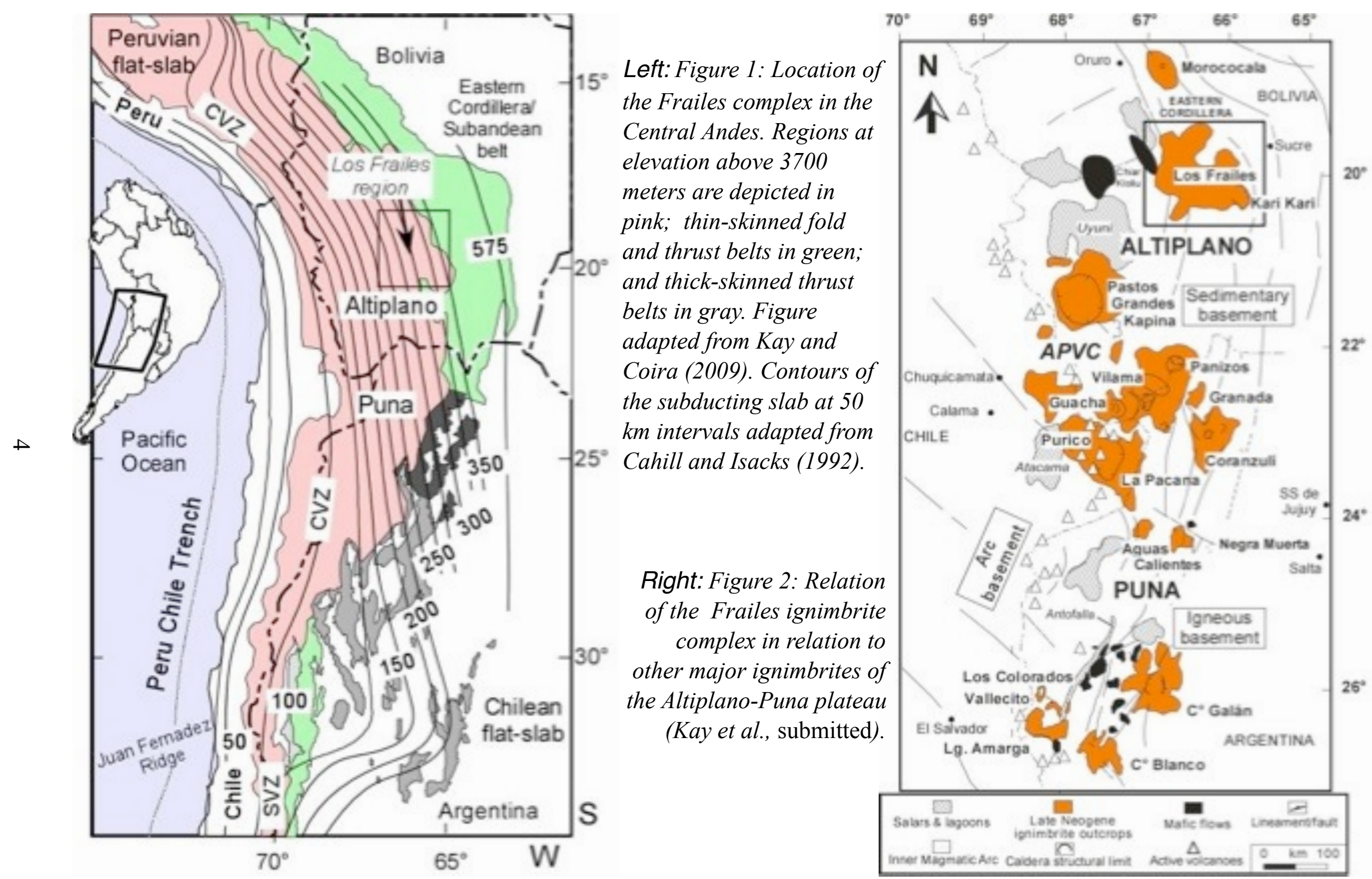
et al. (1997) and Luedke et al. (1997). The data presented here helps to bridge the current gap in understanding of the Frailes ignimbrites and provide a basis for a revised geological and geochemical interpretation of the complex.

\section{Geologic Setting}

The Frailes ignimbrite complex stretches between 19 and 20 degrees $\mathrm{S}$ at the boundary between the Eastern Cordillera to the east and the Bolivian Altiplano to the west (Figures 1 and 2). The peraluminous andesitic to rhyodacitic (Schneider, 1985; Jimenez et al., 1997) ashflow tuffs of the Frailes complex unconformably overlie the sedimentary sequences of the Eastern Cordillera fold and thrust belt, which is comprised of Ordovician shales and Cretaceous syn-rift sandstones, as well as younger continental redbeds and interbedded volcanics of the Tertiary Mondragon Formation (e.g. Schneider and Halls, 1985; Kennan et al., 1995). As shown in Figures 2 and 3, the Frailes complex extends over $110 \mathrm{~km}$ north-south and nearly $100 \mathrm{~km}$ east-west, centered on the massive main Frailes Meseta. While the volume of volcanic ejecta contained in the Frailes complex is not well constrained, Schneider and Halls (1985) estimated a total volume $2000 \mathrm{~km}^{3}$ for the 1 to $25 \mathrm{Ma}$ volcanics in the complex. In addition, the Frailes ignimbrite complex is notable for the magnitude of its associated mineralization. Polymetallic sulfide mineralization of variable degree is widespread throughout the vicinity of the Frailes complex, especially at Potosí and Porco on the southeastern edge of the main Frailes ignimbrite. Metallogenic deposits of the region are characterized by Sn-Ag mineralization - suggesting a reduced chemistry - along with additional $\mathrm{Zn}, \mathrm{Pb}, \mathrm{Sb}, \mathrm{Bi}$, As, and W mineralization (Schneider, 1987; Rice et al., 2005; Risse et al., 2008). Most 


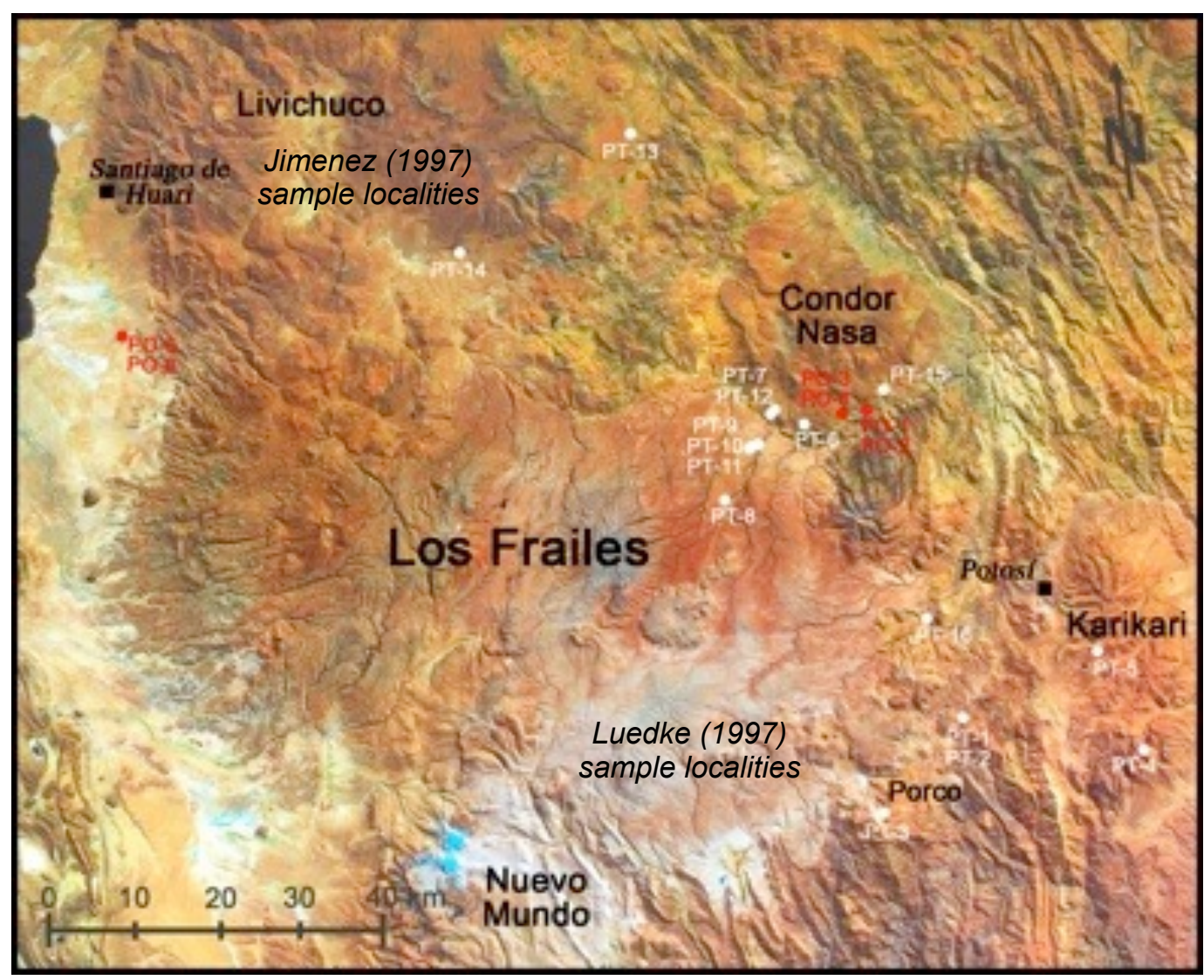

Figure 3. Thematic Mapper satellite image of the Frailes complex showing sample locations; samples in red collected in 2009, those in white collected in 2010.

notably, Cerro Rico, an extensively altered Miocene rhyodacite dome above the city of

Potosí, has been cited as the largest silver deposit on earth (see Schneider, 1985).

Data from seismic surveys of the Altiplano-Puna plateau indicate the presence of pronounced crustal and mantle low velocity anomalies in close alignment with the large Frailes ignimbrite complex.The lithospheric-scale cross-section of Beck and Zandt (2002) in Figure 4 illustrates the dramatic upper-mantle low velocity zone identified by Myers et al. (1998) at the boundary between the Altiplano and the Eastern Cordillera, directly beneath the Frailes complex. This zone of low seismic Vp and Vs is suggestive of high temperatures, and has been interpreted as a region of missing or profoundly modified 


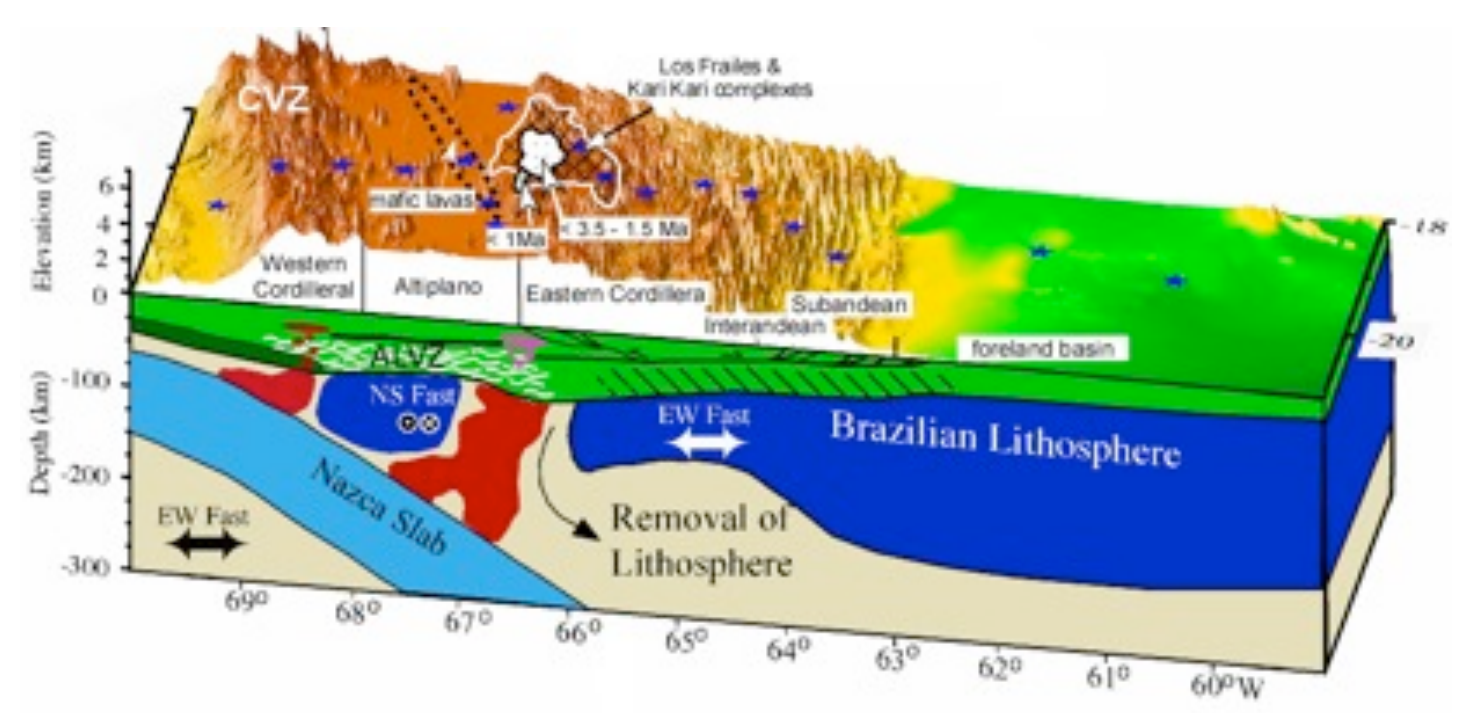

Figure 4: Composite lithospheric cross section from Beck and Zandt (2002) showing the location of the Frailes complex with respect to the crustal Altiplano Low Velocity Zone (see Yuan et al. 2002) and the mantle low velocity zone (Myers et al., 1998) attributed to removal of lithosphere. Extent of $<3.5 \mathrm{Ma}$ volcanics in Frailes region is based on Barke et al. (2007). Stars show location of seismic stations (see discussion in Beck and Zandt, 2002). Figure is as modified by Kay and Coira (2009).

mantle lithosphere (Beck and Zandt, 2002). These observations are in accordance with the understanding of Los Frailes as a large, recently active volcanic center, and the high temperature and missing mantle lithosphere suggest the possibility of delamination and delamination-induced magmatism, as reviewed by Kay and Coira (2009). The presence of thick crust $(\sim 65 \mathrm{~km})$, but absence of a thick lower-crustal high-velocity region under Los Frailes is similarly consistent with crustal delamination (Beck et al., 1996; Beck and Zandt, 2002) of the style suggested by Kay et al. (1994). Furthermore, receiver function studies by Beck and Zandt (2002) noted a small, shallow, low velocity-high Lg attenuation-high $\mathrm{Vp} / \mathrm{Vs}$ region between 14 and $20 \mathrm{~km}$ depth (pink region in mid-crust in Figure 4), also directly beneath Los Frailes. This region, to the east of the similar but larger Altiplano low-velocity zone (ALVZ) of Yuan et al., (2001) may be interpreted as a 
crustal zone of partial melt - indicating recent, if not contemporary, surficial magmatic activity at Los Frailes.

At or since the time of volcanism, the main eruptive centers of the Frailes complex have been obscured, with no obvious caldera immediately visible. However, the Frailes eruptives may be separated into broad mesetas each with distinct source regions. As seen in Figure 3, the Livichuco and Condor Nasa Mesetas are located to the north and northeast of the main Frailes Meseta, respectively, while the remnants of the Karikari Caldera and associated ignimbrites are situated to the southeast. A working chronology of

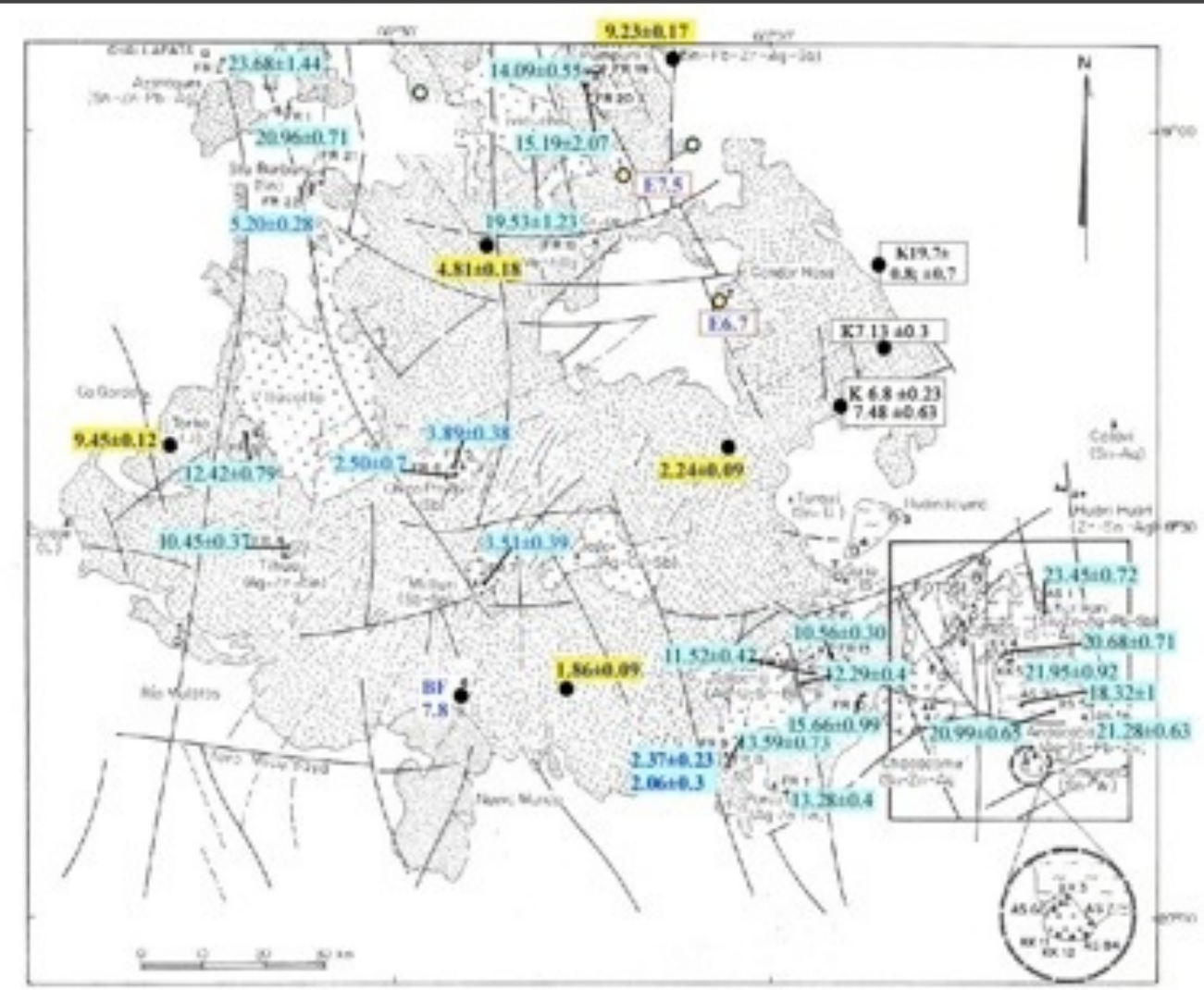

Figure 5: Distribution of ages in the Frailes ignimbrite complex, adapted from Schneider, 1987. Dates prefixed ' $E$ ' are K-Ar ages from Evernden et al., 1977; dates prefixed 'BF are K-Ar ages from Baker and Francis, 1978 ; light blue dates are K-Ar ages from Schneider and Halls, 1985; dates prefixed ' $K$ ' are $K$-Ar ages from Kennan et al., 1995; dates highlighted yellow are Ar-Ar ages from Barke et al., 2007. All ages on biotite. 
the Frailes mesetas may be deduced from existing geochronological studies, a summary of which is shown in Figure 5.

According to Schneider and Halls (1985), the Frailes volcanic zone is marked by five discrete magmatic episodes. The first episode, at about $25 \mathrm{Ma}$, produced little volume, with only the small Kumurana granodiorite pluton in the southeast of the Frailes complex and the ignimbrite deposits at Azanaques in the northwest thought to have originated at this time. During the second episode, around $20 \mathrm{Ma}$, activity escalated most notably including the formation of the Karikari caldera (inset at lower right of Figure 5), as well as some eruptive activity in the north of the Frailes complex near the town of Cruce Ventilla and in the east near Agua Dulce. The Azanaques granite, the second and final intrusive after the Kumurana granodiorite, was also emplaced during the second stage. From 10-17 Ma - the third episode - volcanism occured throughout the central region of the Frailes complex, producing the widespread upper and lower Cebadillas ashflow deposits. Based on ages available at the time (shown in blue in Figure 5), Schneider and Halls (1985) placed the main Frailes ignimbrite in a fourth episode, from 5-8 Ma. The final "post-Frailes" fifth episode was argued to have formed the resurgent Cerro Torro and Viacollo domes (center of Figure 5) from 4-1 Ma. However, recent dating by Barke et al. (2007) suggests that the main Frailes ignimbrite (fourth stage) may be significantly younger than the 5-8 Ma reported by Schneider and Halls (1985). As shown in Figure 5, the recent biotite Ar-Ar ages of Barke et al. (2007) from the northeastern and southeastern margins of the main Frailes Meseta (highlighted yellow in Figure 5) show dates of 2.24 and 1.86+/- 0.09 Ma, respectively, suggesting a much 
younger age for the main Frailes Meseta - closer in timing to the dome emplacement of the fifth stage. This possibility is consistent with the geophysical data, as the presence of the significant upper-mantle low-velocity zone beneath Los frailes is most consistent with massive recent volcanism.

Prior geochemical work on the bulk of the Frailes ignimbrite has been limited, with only three studies reporting data from the main (non-metallogenic) volume of the complex: the $\mathrm{PhD}$ thesis of Schneider (1985), containing data from across the plateau; Jimenez et al. (1997) on the Livichuco Meseta; and Luedke et al. (1997) on the southern part of the complex. Of these, Luedke et al. (1997) and Jimenez et al. (1997) approach Los Frailes from a generally local standpoint and provide relatively little regional or lithospheric-scale interpretation, while Schneider (1985) uses the data mainly to provide context for the associated mineralization. Other volcanic units of interest in the region that have been the subject of some prior study include the Morococala ignimbrite $\sim 75 \mathrm{~km}$ to the north and the mafic lavas to the west e.g. Davidson and de Silva (2005) and Hoke and Lamb (2008)(Figure 2). Morgan et al. (1998) present a study of the highly peraluminous rocks of the Morococala ignimbrite, noting an exotic (for an ignimbrite) mineral assemblage including andalusite and cordierite. Given the close geographical location and similar peraluminous composition, some similarities may be expected between the Frailes and Morococala ignimbrites; Ar-Ar isochron ages from Morococala record dates of 6.4 to $8.4 \mathrm{Ma}$ (Koeppen et al., 1987) within the time period during which the Frailes complex was active, and in line with the original estimates for the age of the eruption of the main Frailes Meseta (Schneider and Halls, 1987). Other nearby units 
include outcrops of shoshonites and basaltic andesites to the west (Figures 2 and 3), which Hoke and Lamb (2007) model as originating from partial melt of an enriched MORB source at depths between 65 and $95 \mathrm{~km}$.

\section{Experimental Methodology}

Ignimbrite samples (Table 1) were collected during two field expeditions to the Frailes complex - in 2009 during a reconnaissance trip by S.M. Kay and B.L Coira, and in March 2010 as part of this study. Sample locations for the 25 pumice and welded tuff samples are illustrated in Figure 3, with coordinates given in Table 1. Samples were selected and trimmed in the field to minimize the effect of weathering. Petrological, mineralogical, and geochemical data were collected on the ignimbrite samples using electron probe microanalysis, instrumental neutron activation analysis (INAA), and X-ray fluorescence spectroscopy (XRF). In order to avoid contamination and minimize systematic error between techniques in the chemical analyses, all wholerock analyses were conducted on the same bulk-rock powders mechanically pulverized in an alumina shatter-box.

Whole-rock major element and $\mathrm{Rb}, \mathrm{Nb}, \mathrm{Y}$, and $\mathrm{Zr}$ chemistries were determined by X-ray fluorescence at the University of Jujuy in Argentina, following analytical methodology as discussed by Caffe at al. (2002). Whole-rock trace element analyses by INAA were conducted at Cornell University after sample irradiation at the North Carolina State University PULSTAR research reactor. Prior to neutron irradiation, samples and standards were prepared by sealing bulk rock powder of known mass $(\sim 0.5 \mathrm{~g})$ in highpurity silica glass ampoules. Following irradiation, ampoules were individually placed in an ORTEC GEM-20170-S solid-state $\gamma$-ray spectrometer and counted for 3-10 hours each 
Table 1: Samples and locations.

\begin{tabular}{|c|c|c|c|c|c|c|}
\hline Sample & Region & Type & Latitude & Longitude & Altitude & Age \\
\hline PO-1 & Condor Nasa & Ashflow tuff & S 19.3637 & W 65.9355 & $3600 \mathrm{~m}$ & 7-10 Ma \\
\hline PO-2 & Condor Nasa & Ashflow tuff & S 19.3637 & W 65.9355 & $3600 \mathrm{~m}$ & $7-10 \mathrm{Ma}$ \\
\hline PO-3 & Condor Nasa & Ashflow tuff & S 19.3687 & W 65.9637 & $3819 \mathrm{~m}$ & 7-10 Ma \\
\hline $\mathrm{PO}-4$ & Condor Nasa & Ashflow tuff & S 19.3687 & W 65.9637 & $3819 m$ & 7-10 Ma \\
\hline PO-5 & Huari & Ashflow tuff & S 19.1733 & W 66.7811 & $3721 \mathrm{~m}$ & 1-4 Ma \\
\hline PO-6 & Huari & Ashflow tuff & S 19.1733 & W 66.7811 & $3721 \mathrm{~m}$ & 1-4 Ma \\
\hline PT-1 & Porco & Ashflow tuff & S 19.71020 & W 65.87138 & $3916 \mathrm{~m}$ & $12-14 \mathrm{Ma}$ \\
\hline PT-2 & Porco & Ashflow tuff & S 19.71020 & W 65.87138 & $3916 \mathrm{~m}$ & $12-14 \mathrm{Ma}$ \\
\hline PT-3 & Porco & Intrac. tuff & S 19.80210 & W 65.97706 & $4080 \mathrm{~m}$ & $12-14 \mathrm{Ma}$ \\
\hline PT-4 & Kumurana & Intrusive & S 19.77537 & W 65.67075 & $4586 m$ & $25 \mathrm{Ma}$ \\
\hline PT-5 & Karikari & Ashflow tuff & S 19.36375 & W 65.70851 & $4361 \mathrm{~m}$ & $20 \mathrm{Ma}$ \\
\hline PT-6 & Condor Nasa & Ashflow tuff & S 19.36858 & W 66.00847 & $4042 \mathrm{~m}$ & $7-10 \mathrm{Ma}$ \\
\hline PT-7 & Condor Nasa & Ashflow tuff & S 19.35165 & W 66.04090 & $3890 \mathrm{~m}$ & $7-10 \mathrm{Ma}$ \\
\hline PT-8 & Los Frailes & Ashflow tuff & S 19.44460 & W 66.11150 & $3943 \mathrm{~m}$ & $\sim 2 \mathrm{Ma}$ \\
\hline PT-9 & Los Frailes & Ashflow tuff & S 19.38651 & W 66.07663 & $3889 \mathrm{~m}$ & $\sim 2 \mathrm{Ma}$ \\
\hline PT-9p & Los Frailes & Pumice & S 19.38651 & W 66.07663 & 3889 m & $\sim 2 \mathrm{Ma}$ \\
\hline PT-10 & Los Frailes & Pumice & S 19.38712 & W 66.07063 & $3824 \mathrm{~m}$ & $2.24 \mathrm{Ma}$ \\
\hline PT-11 & Los Frailes & Ashflow tuff & S 19.38523 & W 66.06510 & $3720 \mathrm{~m}$ & $2.24 \mathrm{Ma}$ \\
\hline PT-11p & Los Frailes & Pumice & S 19.38523 & W 66.06510 & $3720 \mathrm{~m}$ & $2.24 \mathrm{Ma}$ \\
\hline PT-12 & Condor Nasa & Ashflow tuff & S 19.35593 & W 66.04590 & 3762 m & 7-10 Ma \\
\hline PT-13 & Livichuco & Ashflow tuff & S 19.02840 & W 66.16620 & $4077 \mathrm{~m}$ & 7-10 Ma \\
\hline PT-14 & Livichuco & Ashflow tuff & S 19.13400 & W 66.37816 & $4107 \mathrm{~m}$ & 7-10 Ma \\
\hline PT-15 & Condor Nasa & Ashflow tuff & S 19.34906 & W 65.91299 & 3757 m & $7.13 \mathrm{Ma}$ \\
\hline PT-16 & Los Frailes & Ashflow tuff & S 19.60108 & W 65.89838 & $3589 \mathrm{~m}$ & $\sim 2 \mathrm{Ma}$ \\
\hline PT-16b & Los Frailes & Silicic lava & S 19.60108 & W 65.89838 & $3589 \mathrm{~m}$ & $\sim 2 \mathrm{Ma}$ \\
\hline
\end{tabular}


to determine each sample's emission spectrum, which was then interpreted by

comparison to three in-house standards, correcting for decay and interferences (standard analyses shown in Appendix I for reference). In order to obtain a more complete set of analyses of elements with both short- and long-half-life radioisotopes, samples were counted twice: first for $\sim 3$ hours each, beginning seven days after irradiation; and second for $\sim 10$ hours each, starting 30 days after irradiation.

Electron probe microanalysis and optical microscopy were conducted at Cornell using standard polished petrographic thin sections. Mineral chemistry was determined via wavelength-dispersive spectroscopy using a JEOL 8900 electron microprobe at the Cornell Center for Materials Research. Analyses were conducted with an accelerating voltage of $15 \mathrm{kV}$, a beam current of $25 \mathrm{nA}$, a beam diameter of 10 microns, and conductive carbon-coating of approximately $20 \mathrm{~nm}$ thickness. The probe standards used were polished, carbon-coated mineral standards from the Smithsonian institution; standard analyses are given in Appendix II.

The samples best characterized to date are samples PO-1 through PO-6, collected in the north of the Frailes complex at coordinates listed in Table 1. As can be seen in Figure 3, these samples originate from two distinct regions: PO-1 through PO-4 are from the Condor Nasa massif in the east, and PO-5 through PO-6 were collected south of the town of Santiago de Huari in the west (see Figure 3). The remaining PT- series samples, collected from locations throughout the Frailes complex in March of 2010, have thus far been only analyzed for trace elements by instrumental neutron activation analysis. 


\section{Mineralogy and Petrography}

As discussed above, the mineral and whole-rock chemistry of samples PO-1 to PO-6 from the Frailes complex were studied using electron probe microanalysis, optical microscopy, and X-ray fluorescence. Whole-rock major element chemical analyses, as determined by X-ray fluorescence, are summarized in Tables 2-3; results of electron microprobe analysis are summarized in Tables 4-8. Not unlike ignimbrite samples from other large Andean ignimbritic volcanic complexes (e.g. Coira et al., 1993; de Silva and Gosnold, 2007), samples PO-1 to PO-6 were found to be compositionally intermediateto-silicic welded ashfall tuffs containing $60-70 \%$ silica (Table 2). All analyzed samples are highly peraluminous, as indicated by their high $\mathrm{Al} /(\mathrm{Ca}+\mathrm{Na}+\mathrm{K})$ atomic rations (Figure 6) and their corundum-normative character (Table 3).

In thin section, the samples exhibit textures typical of a welded tuff, with abundant phenocrysts in a glassy groundmass displaying eutaxitic texture, preferential

Table 2: Whole-Rock Major Element Analyses of samples PO-1 to PO-6 (weight \%).

\begin{tabular}{lcccccc}
\hline & PO-1 & PO-2 & PO-3 & PO-4 & PO-5 & PO-6 \\
\cline { 2 - 6 } SiO2 & 58.98 & 60.29 & 61.11 & 62.82 & 71.97 & 65.76 \\
TiO2 & 1.27 & 1.30 & 1.30 & 1.01 & 0.34 & 0.78 \\
Al2O3 & 18.39 & 18.19 & 18.24 & 17.82 & 14.84 & 16.82 \\
$\mathrm{FeO}$ & 5.90 & 5.30 & 5.40 & 3.19 & 1.92 & 3.41 \\
$\mathrm{MnO}$ & 0.08 & 0.06 & 0.06 & 0.03 & 0.02 & 0.04 \\
$\mathrm{MgO}$ & 2.46 & 2.43 & 2.36 & 1.26 & 0.64 & 1.12 \\
$\mathrm{CaO}$ & 4.00 & 4.23 & 4.18 & 2.49 & 1.69 & 3.22 \\
$\mathrm{Na2O}$ & 1.69 & 2.02 & 2.36 & 2.31 & 2.66 & 2.94 \\
$\mathrm{~K} 2 \mathrm{O}$ & 4.04 & 4.37 & 4.50 & 5.75 & 4.82 & 4.93 \\
$\mathrm{P} 2 \mathrm{O} 5$ & 0.50 & 0.51 & 0.51 & 0.45 & 0.21 & 0.39 \\
LOI & 2.91 & 1.50 & 0.68 & 3.13 & 1.31 & 0.86 \\
Total & 100.2 & 100.2 & 100.7 & 100.3 & 100.4 & 100.3 \\
\hline
\end{tabular}


Table 3: CIPW Normative Mineralogy of samples PO-1 through PO-6 (weight \%).

\begin{tabular}{lrrrrrr}
\hline & PO-1 & PO-2 & PO-3 & PO-4 & PO-5 & PO-6 \\
\cline { 2 - 7 } quartz & 19.58 & 17.79 & 16.24 & 19.92 & 32.95 & 20.49 \\
orthoclase & 23.88 & 25.80 & 26.59 & 34.00 & 28.46 & 29.12 \\
albite & 14.33 & 17.09 & 19.99 & 19.55 & 22.52 & 24.86 \\
anorthite & 16.58 & 17.66 & 17.41 & 9.42 & 7.05 & 13.47 \\
corundum & 5.15 & 3.67 & 3.10 & 4.34 & 2.67 & 1.71 \\
apatite & 1.25 & 1.27 & 1.27 & 1.13 & 0.52 & 0.97 \\
ilmenite & 2.41 & 2.47 & 2.46 & 1.91 & 0.64 & 1.49 \\
magnetite & 1.02 & 0.92 & 0.93 & 0.55 & 0.33 & 0.59 \\
hypersthene & 13.27 & 12.20 & 12.18 & 6.43 & 4.03 & 6.83 \\
Total & 97.46 & 98.86 & 100.17 & 97.25 & 99.17 & 99.52 \\
\hline
\end{tabular}

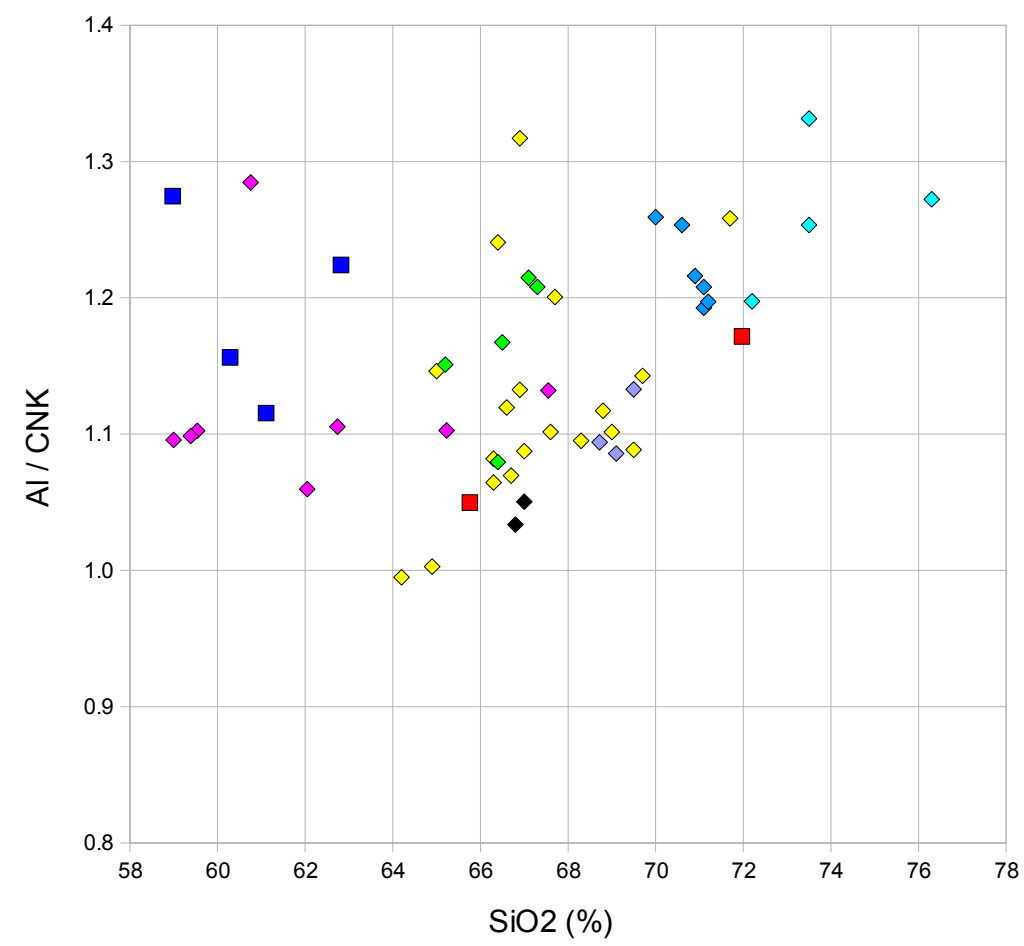

- Nuevo Mundo (Luedke, 1997)

$\diamond$ Porco (Luedke, 1997)

$\diamond$ Frailes (Luedke, 1997)

Huari

Livichuco (Jimenez, 1997)

- Condor Nasa

$\diamond$ Morococala And. Rhy. (Morgan, 1998)

$\diamond$ Morococala Cord. Rhy. (Morgan, 1998)

$\diamond$ Morococala Qtz Latite (Morgan, 1998)

Figure 6: Molar $\mathrm{Al}_{2} \mathrm{O}_{3} /\left(\mathrm{CaO}+\mathrm{Na}_{2} \mathrm{O}+\mathrm{K}_{2} \mathrm{O}\right)$ versus $\mathrm{SiO}_{2}$ weight percent for representative ignimbrite samples from the Livichuco and Los Frailes complexes.

orientation of elongate phenocrysts, and occasional axiolitic texture (a type of fibrous intergrowth that is linear in macroscopic form) from devitrification. The samples contain 
a phenocryst assemblage including many minerals common to other large Andean ignimbrites, such as biotite, quartz, tridymite, sanidine, plagioclase, and orthopyroxene (e.g. Coira et al., 1993), as well as more atypical constituents such as cordierite and calcic plagioclase (to AN 80; Table 4). Although lateral and stratigraphic variations in composition and mineralogy within each region are not well constrained, the differences between the two sample groups are clear: samples PO-1,3, and 4 from the Condor Nasa Meseta were categorized as moderately crystal-rich (35-50\% phenocrysts) biotite andesite ignimbrite $\left(58-63 \% \mathrm{SiO}_{2}\right.$; Table 2), with phenocryst proportions of up to $45 \%$ each of biotite and calcic plagioclase, as well as $0-20 \%$ quartz and tridymite, $0-6 \%$ hypersthene, and $0-2 \%$ cordierite. In contrast, samples PO-5 and PO-6 from south of Santiago de Huari (Referred to as Huari samples below; Figure 3) are highly crystal-rich (60-65\% phenocrysts by volume), significantly more silicic rhyodacites $\left(65-70 \% \mathrm{SiO}_{2}\right.$; Table 2 ), containing roughly $20 \%$ sanidine and $40 \%$ quartz + tridymite, along with approximately $30 \%$ plagioclase, $10-15 \%$ biotite and no orthopyroxene or cordierite. Accessory $(<1 \%$ of phenocrysts by volume $)$ minerals zircon, ilmenite, and apatite were found throughout all samples. With the exception of PO-4, the samples display little evidence of weathering or alteration.

In the Condor Nasa samples, textural relations indicate that plagioclase may have been the first major silicate phase to crystallize, as it lacks inclusions of any other major silicate mineral. Biotite, the other main phase in the Condor Nasa samples contains abundant inclusions of plagioclase and other silicates. In contrast, the Huari samples exhibit the inverse relationship, with many phenocrysts of biotite included in larger 
plagioclase grains. Biotite phenocrysts are generally rectilinear due to cleavage, and often bent, reflecting strain incurred during eruption. Further, biotite is frequently associated with opaque Fe-Ti oxides, and many phenocrysts were found to have ragged (embayed), corroded margins. Plagioclase in all samples displays clear oscillatory zoning. Feldspar phenocrysts are frequently fractured and anhedral, but do not display any corrosion or resorption at their margins. In contrast, quartz and tridymite phenocrysts are consistently rounded and embayed, and exhibit clear conchoidal fracture internally. Texturally, quartz and tridymite in the Frailes samples are identical, with tridymite identified by its biaxial optical character and slightly higher birefringence. In all six samples, quartz and tridymite phenocrysts contain inclusions of both plagioclase and biotite, suggesting later crystallization. Sanidine, which is present in samples PO-5 and 6, is pseudouniaxial, with a $2 \mathrm{~V}$ of zero, and contains inclusions of plagioclase and biotite. In addition, small crystals of apatite, zircon, and ilmenite were found as inclusions and occasionally as free crystals in the glassy groundmass. Zircon and ilmenite were found to be texturally very early, present as inclusions even in the first of the major silicate phases to crystallize.

Notably, sample PO-2 from

Condor Nasa contains phenocrysts of the aluminosilicate mineral cordierite. PO-2 is also distinct from the other samples analyzed in that it lacks quartz and tridymite, and contains approximately $6 \%$ hypersthene by phenocryst volume.

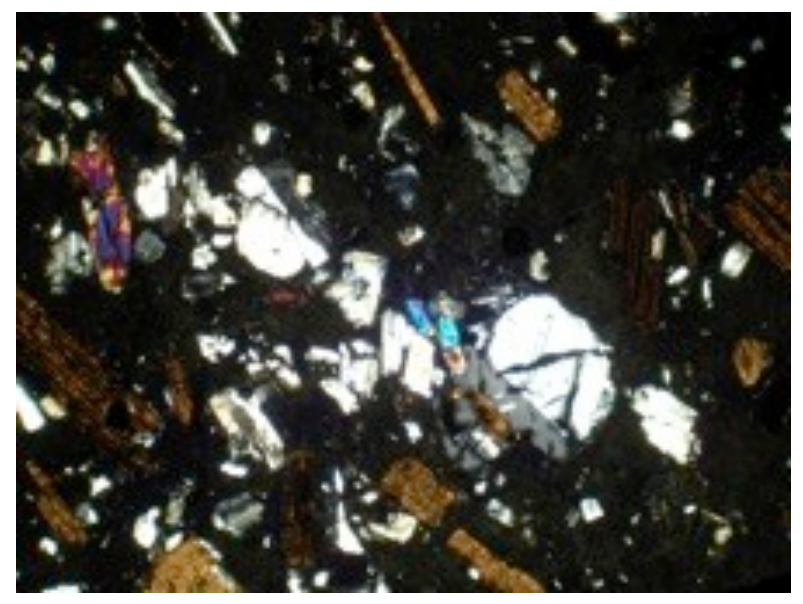

Figure 7: Photomicrograph of cordierite in sample PO-2 in cross-polarized illumination. 
In plane-polarized light, the cordierite displays characteristic violet-to-colorless

pleochroism, suggesting moderate to high iron content. As shown in Figure 7, cordierite is texturally associated with the orthopyroxene, and contains inclusions of biotite and

Table 4: Representative microprobe analyses of plagioclase and sanidine.

\begin{tabular}{|c|c|c|c|c|c|}
\hline & po1-5 plag 1 & po2-5 plag 1 & po2-5 plag 2 & po3-2 plag 1 & po5-1 plag 2 \\
\hline$A n \%$ & 58.70 & 70.11 & 79.08 & 44.55 & 26.19 \\
\hline$A b \%$ & 39.23 & 28.41 & 20.17 & 51.69 & 69.79 \\
\hline Or\% & 2.07 & 1.48 & 0.75 & 3.77 & 4.02 \\
\hline $\mathrm{SiO} 2$ & 53.33 & 50.52 & 48.20 & 56.90 & 61.30 \\
\hline TiO2 & 0.01 & 0.04 & 0.03 & 0.01 & 0.02 \\
\hline $\mathrm{Al} 2 \mathrm{O} 3$ & 28.83 & 31.31 & 32.71 & 26.67 & 23.49 \\
\hline $\mathrm{FeO}$ & 0.07 & 0.32 & 0.20 & 0.06 & 0.00 \\
\hline $\mathrm{MnO}$ & 0.02 & 0.00 & 0.03 & 0.03 & 0.02 \\
\hline $\mathrm{MgO}$ & 0.02 & 0.02 & 0.01 & 0.00 & 0.01 \\
\hline $\mathrm{CaO}$ & 11.85 & 14.30 & 16.05 & 9.08 & 5.36 \\
\hline $\mathrm{Na} 2 \mathrm{O}$ & 4.38 & 3.20 & 2.26 & 5.82 & 7.89 \\
\hline $\mathrm{K} 2 \mathrm{O}$ & 0.35 & 0.25 & 0.13 & 0.65 & 0.69 \\
\hline \multirow[t]{2}{*}{ Total } & 98.86 & 99.97 & 99.62 & 99.22 & 98.78 \\
\hline & po6-1 plag 1 & po5-2 ksp 1 & po5-2 ksp 2 & po6-4 ksp 1 & po6-4 ksp 2 \\
\hline$A n \%$ & 38.95 & 0.49 & 0.48 & 0.67 & 0.82 \\
\hline$A b \%$ & 56.89 & 21.65 & 23.01 & 17.92 & 19.16 \\
\hline Or\% & 4.16 & 77.87 & 76.51 & 81.41 & 80.01 \\
\hline $\mathrm{SiO} 2$ & 57.97 & 64.63 & 64.45 & 64.61 & 64.74 \\
\hline TiO2 & 0.01 & 0.01 & 0.00 & 0.02 & 0.02 \\
\hline $\mathrm{Al} 2 \mathrm{O} 3$ & 25.95 & 18.52 & 18.76 & 18.40 & 17.89 \\
\hline $\mathrm{FeO}$ & 0.09 & 0.00 & 0.03 & 0.04 & 0.01 \\
\hline $\mathrm{MnO}$ & 0.00 & 0.01 & 0.00 & 0.00 & 0.00 \\
\hline $\mathrm{MgO}$ & 0.00 & 0.02 & 0.02 & 0.00 & 0.01 \\
\hline $\mathrm{CaO}$ & 8.01 & 0.10 & 0.10 & 0.14 & 0.16 \\
\hline $\mathrm{Na} 2 \mathrm{O}$ & 6.46 & 2.44 & 2.58 & 2.02 & 2.09 \\
\hline K2O & 0.72 & 13.37 & 13.03 & 13.96 & 13.28 \\
\hline Total & 99.21 & 99.09 & 98.97 & 99.18 & 98.20 \\
\hline
\end{tabular}


plagioclase. These inclusions suggest a primary magmatic origin for the cordierite, and indicate later crystallization. Cordierite phenocrysts range from euhedral to anhedral, but consistently show corroded, slightly

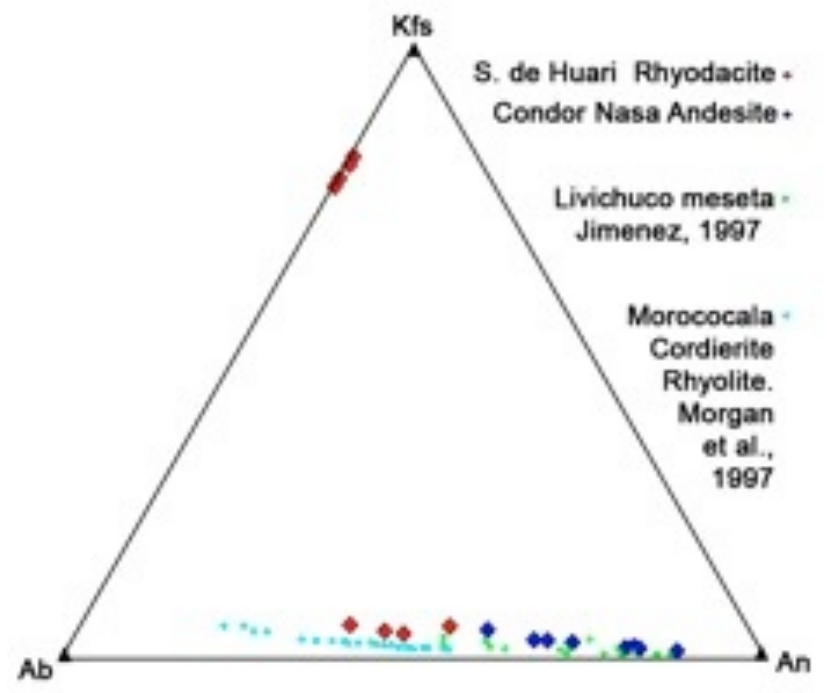

Figure 8: Plagioclase composition diagram. samples (PO1-4) range from AN 50-AB 48 - OR 2 to AN 79 - AB 20 - OR 1, whereas those in the more felsic Huari samples range from AN $26-\mathrm{AB} 70-\mathrm{OR} 4$ to $\mathrm{AN} 40-\mathrm{AB}$ 56 - OR 4 (Figure 8, Table 4). As seen in Figure 8, plagioclase from Condor Nasa plots near that of samples from the adjacent Livichuco Meseta as analyzed by Jimenez et al. (1997), whereas feldspars from the Morococala ignimbrite farther north (Morgan et al, 1997) were found to be significantly more albitic, in accordance with the more felsic nature of the rhyolitic ignimbrites at Morococala.

\section{Biotite:}

As shown in Table 5 and Figure 9, biotite from the Frailes complex is highly aluminous and does not plot on the annite-phogopite solid solution line of Figure 9, as it contains significant components of eastonite $\left(\mathrm{K}_{2}\left[\mathrm{Mg}_{5} \mathrm{Al}\right]\left[\mathrm{Si}_{5} \mathrm{Al}_{3}\right] \mathrm{O}_{20}(\mathrm{OH}, \mathrm{F})_{4}\right)$ and siderophyllite $\left(\mathrm{K}_{2}\left[\mathrm{Fe}^{2+}{ }_{5} \mathrm{Al}\right]\left[\mathrm{Si}_{5} \mathrm{Al}_{3}\right] \mathrm{O}_{20}(\mathrm{OH}, \mathrm{F})_{4}\right)$. Biotite from the Condor Nasa andesite plots nearly in the center of the diagram, with roughly equal atomic proportions of Fe and Mg. The much less abundant biotite from the Huari rhyodacite is slightly more Fe-rich 


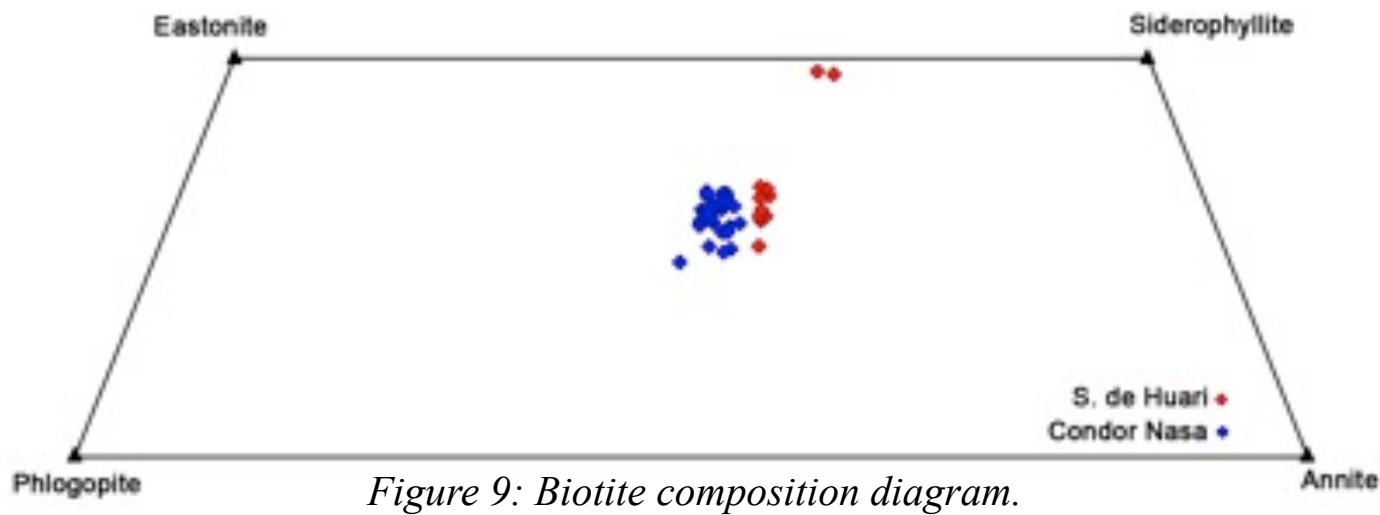

Table 5: Representative microprobe analyses of high-and low-Fe biotite.

\begin{tabular}{|c|c|c|c|c|c|c|}
\hline & P01-1 bt 2 & PO1-1 bt 5 & PO1-4 bt 1 & $\mathrm{PO}-1$ bt 1 & PO2-1 bt 4 & PO2-8 bt 3 \\
\hline $\mathrm{Mg} \#$ & 46.79 & 47.38 & 46.94 & 48.21 & 48.42 & 48.39 \\
\hline $\mathrm{SiO} 2$ & 33.99 & 35.77 & 35.83 & 36.47 & 35.75 & 35.73 \\
\hline TiO2 & 5.30 & 5.28 & 5.27 & 5.22 & 5.46 & 5.38 \\
\hline $\mathrm{Al} 2 \mathrm{O} 3$ & 16.44 & 16.30 & 16.35 & 16.02 & 15.91 & 16.15 \\
\hline $\mathrm{FeO}$ & 20.21 & 20.55 & 21.09 & 20.22 & 20.70 & 20.75 \\
\hline $\mathrm{MnO}$ & 0.15 & 0.15 & 0.14 & 0.09 & 0.08 & 0.09 \\
\hline $\mathrm{MgO}$ & 9.97 & 10.38 & 10.47 & 10.56 & 10.91 & 10.91 \\
\hline $\mathrm{CaO}$ & 0.03 & 0.05 & 0.00 & 0.09 & 0.01 & 0.00 \\
\hline $\mathrm{Na} 2 \mathrm{O}$ & 0.29 & 0.42 & 0.44 & 0.49 & 0.55 & 0.50 \\
\hline K2O & 8.67 & 8.89 & 9.09 & 8.85 & 8.94 & 9.03 \\
\hline \multirow[t]{2}{*}{ Total } & 95.04 & 97.80 & 98.67 & 98.00 & 98.32 & 98.53 \\
\hline & PO3-3 bt 2 & PO4-2 bt 3 & PO5-e bt 1 & PO5-e bt 2 & PO6-3 bt 2 & PO6-3 bt 1 \\
\hline Mg \# & 46.77 & 46.78 & 36.06 & 37.77 & 43.66 & 43.59 \\
\hline $\mathrm{SiO} 2$ & 35.77 & 34.98 & 35.11 & 35.13 & 35.75 & 36.02 \\
\hline TiO2 & 5.26 & 4.91 & 3.84 & 3.95 & 4.53 & 4.67 \\
\hline $\mathrm{Al} 2 \mathrm{O} 3$ & 16.23 & 15.60 & 18.97 & 19.03 & 16.34 & 16.58 \\
\hline $\mathrm{FeO}$ & 20.97 & 20.65 & 23.88 & 23.37 & 21.79 & 21.70 \\
\hline $\mathrm{MnO}$ & 0.13 & 0.14 & 0.19 & 0.17 & 0.15 & 0.19 \\
\hline $\mathrm{MgO}$ & 10.34 & 10.18 & 7.56 & 7.96 & 9.47 & 9.41 \\
\hline $\mathrm{CaO}$ & 0.00 & 0.00 & 0.03 & 0.00 & 0.08 & 0.00 \\
\hline $\mathrm{Na} 2 \mathrm{O}$ & 0.45 & 0.45 & 0.49 & 0.47 & 0.33 & 0.28 \\
\hline K2O & 9.30 & 9.19 & 9.34 & 9.46 & 9.38 & 9.65 \\
\hline Total & 98.44 & 96.10 & 99.41 & 99.54 & 97.82 & 98.48 \\
\hline
\end{tabular}


and much less homogeneous, with a a clear subpopulation of much more Al-rich micas.

Additionally, the biotite was found to be Ti-rich, containing between 3.5 and $4.5 \% \mathrm{TiO}_{2}$, with more Ti in the more mafic Condor Nasa samples.

\section{Orthopyroxene:}

Orthopyroxene, which was found as a minor phase in samples PO-2 and PO-3, consists of hypersthene with negligible calcium content, as shown in Figure 10 and Table 6. The majority of the orthopyroxene contains near equal amounts of $\mathrm{Fe}$ and $\mathrm{Mg}$, with a

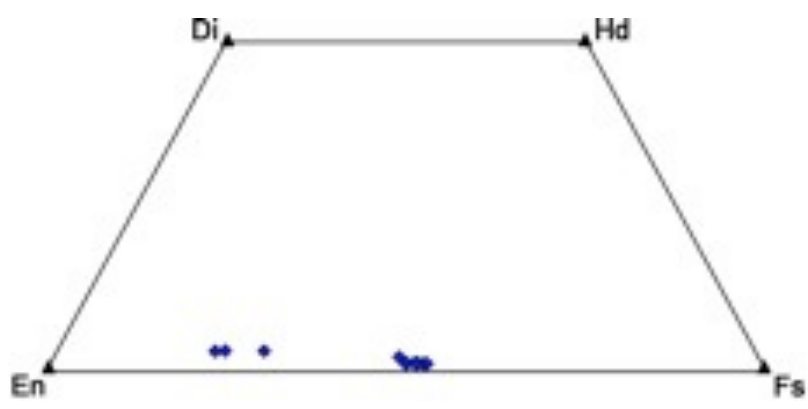

Figure 10: Pyroxene quadrilateral showing composition of pyroxenes from $\mathrm{PO}-2$ and

composition of $\sim$ EN $49-$ FS $49-$ WO

2. However, some orthopyroxene phenocrysts display strong compositional zoning, with Mg-rich interiors up to $80 \%$ En (Table 6). As illustrated in Figure 11, which shows a high-contrast backscattered electron image of an orthopyroxene phenocryst, the $\mathrm{Mg}-\mathrm{Fe}$

Table 6: Representative microprobe analyses of high-and low-Fe orthopyroxene.

\begin{tabular}{lrrrrr}
\hline & po2-1 opx 3 & po2-1 opx 4 & po2-8 opx 2 & po2-4 opx 2 & po2-4 opx 4 \\
\cline { 2 - 6 } $\mathrm{En \%}$ & $\mathbf{5 2 . 0 5}$ & $\mathbf{5 0 . 7 8}$ & $\mathbf{5 0 . 7 2}$ & $\mathbf{7 6 . 6 8}$ & $\mathbf{7 7 . 8 6}$ \\
$\mathrm{SiO} 2$ & 50.05 & 50.95 & 49.52 & 51.52 & 52.36 \\
$\mathrm{TiO} 2$ & 0.17 & 0.10 & 0.20 & 0.41 & 0.38 \\
$\mathrm{Al} 2 \mathrm{O} 3$ & 2.63 & 1.25 & 3.10 & 5.00 & 4.24 \\
$\mathrm{FeO}$ & 28.97 & 29.89 & 29.58 & 14.55 & 13.90 \\
$\mathrm{MnO}$ & 0.65 & 0.77 & 0.73 & 0.21 & 0.17 \\
$\mathrm{MgO}$ & 17.64 & 17.30 & 17.08 & 26.84 & 27.43 \\
$\mathrm{CaO}$ & 0.22 & 0.26 & 0.24 & 1.18 & 1.14 \\
$\mathrm{Na} 2 \mathrm{O}$ & 0.01 & 0.02 & 0.02 & 0.03 & 0.02 \\
$\mathrm{~K} 2 \mathrm{O}$ & 0.00 & 0.00 & 0.00 & 0.00 & 0.00 \\
Total & 100.36 & 100.53 & 100.47 & 99.73 & 99.64 \\
\hline
\end{tabular}


Figure 11: High-contrast backscattered electron image of orthopyroxene showing Mg-Fe zoning. Zoning is visible due to the difference in average atomic number (Z) and thus nuclear cross-section of the elements present: Light areas contain high-Z Fe; dark areas of the orthopyroxene contain lower-Z Mg. Corrosion of the mineral borders is clearly visible.

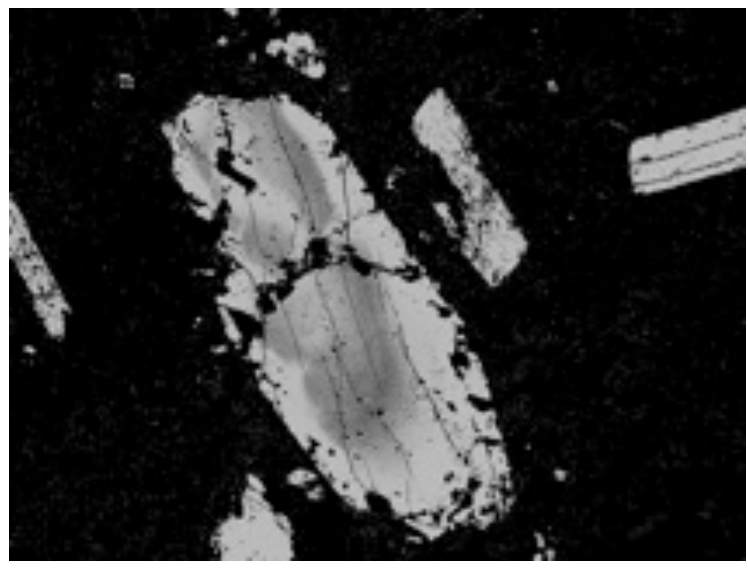

zoning of the orthopyroxene is irregular in pattern, not a clear core-rim overgrowth relationship, suggesting formation by melt infiltration and back-reaction.

\section{Cordierite:}

Cordierite, which was found only in sample PO-2, consists of a solid solution of Mg-cordierite and Fe-cordierite, with the samples analyzed here falling between $65 \%$ and 69\% Mg-cordierite $(\mathrm{Mg} /(\mathrm{Mg}+\mathrm{Fe})$ : $\mathrm{Mg}$ number $)$. Cordierite was spatially associated with pyroxene in PO-2, and was observed to be in textural equilibrium with the Fe-rich population of orthopyroxene. Although it is difficult to rule out a xenocrystic origin for

Table 7: Representative microprobe analyses of cordierite.

\begin{tabular}{|c|c|c|c|c|c|}
\hline \multirow[b]{2}{*}{$\mathrm{Mg} \#$} & \multicolumn{5}{|c|}{ po2-1 cord 1 po2-1 cord 2 po2-1 cord 3 po2-1 cord 4 po2-2 cord 1} \\
\hline & 67.16 & 67.42 & 67.09 & 67.48 & 68.54 \\
\hline $\mathrm{SiO} 2$ & 49.27 & 49.15 & 49.4 & 49.42 & 49.42 \\
\hline TiO2 & 0.01 & 0.01 & 0.01 & 0.05 & 0.00 \\
\hline Al2O3 & 33.50 & 33.62 & 33.37 & 33.06 & 33.28 \\
\hline $\mathrm{FeO}$ & 8.03 & 7.98 & 8.08 & 8.12 & 7.76 \\
\hline $\mathrm{MnO}$ & 0.16 & 0.14 & 0.17 & 0.16 & 0.13 \\
\hline $\mathrm{MgO}$ & 9.21 & 9.27 & 9.24 & 9.45 & 9.49 \\
\hline $\mathrm{CaO}$ & 0.07 & 0.02 & 0.04 & 0.02 & 0.02 \\
\hline $\mathrm{Na} 2 \mathrm{O}$ & 0.10 & 0.05 & 0.06 & 0.02 & 0.05 \\
\hline $\mathrm{K} 2 \mathrm{O}$ & 0.15 & 0.11 & 0.11 & 0.11 & 0.13 \\
\hline Total & 100.49 & 100.36 & 100.47 & 100.40 & 100.28 \\
\hline
\end{tabular}


cordierite in the sample, it appears most likely to be a liquidus phase. On a first-order basis, crystallization of primary cordierite is consistent with the peraluminous bulk rock chemistry of sample PO-2. In addition, the presence of plagioclase and biotite inclusions in cordierite that are compositionally equivalent to the free phenocrysts of plagioclase and biotite in the sample provides evidence for an autochtonous origin, as does the presence of some euhedral phenocrysts.

\section{Sanidine:}

Alkali-feldspar phenocrysts analyzed to date were observed to be K-rich, with compositions of AN 0.5 - OR 76-80 - AB 18-23, as shown in Table 4 and Figure 8. Compositional zoning of sanidine, if present, was not clearly visible in optical or backscattered electron images.

\section{Additional Phases:}

Quartz and tridymite phenocrysts

occurring in samples PO1-6 are nearly pure

silica as might be expected (Table 8).

Accessory phases zircon, apatite, and

ilmenite were not extensively studied by

microprobe analysis. However, the presence

of ilmenite (Table 8) and iron in the Fe(II)

oxidation state is consistent with a

chemically reduced nature of the samples, in
Table 8: Microprobe analyses of additional phases.

\begin{tabular}{lrr}
\hline & po1-8 qtz 1 & po1-4 ilm 1 \\
\cline { 2 - 3 } SiO2 & 99.00 & 0.01 \\
TiO2 & 0.02 & 50.90 \\
Al2O3 & 0.07 & 0.21 \\
$\mathrm{FeO}$ & 0.00 & 48.08 \\
$\mathrm{MnO}$ & 0.01 & 0.78 \\
$\mathrm{MgO}$ & 0.00 & 1.55 \\
$\mathrm{CaO}$ & 0.01 & 0.00 \\
$\mathrm{Na} 2 \mathrm{O}$ & 0.02 & 0.00 \\
$\mathrm{~K} 2 \mathrm{O}$ & 0.00 & 0.00 \\
Total & 99.14 & 101.54 \\
\hline
\end{tabular}

line with known characteristics of the region (see Bolivian tin belt, e.g. Lehmann et al., 1990). 


\section{Geothermometry \& geobarometry:}

Zircon saturation thermometry (Watson and Harrison, 1983) of samples PO-1

through PO-6 yielded whole-rock zircon saturation temperatures between $\sim 810^{\circ}$ and

$\sim 875^{\circ} \mathrm{C}$, as summarized in Table 9 . Given the presence of zircon both as inclusions and

as free grains in the groundmass, along with zircon's texturally early crystallization, it is

plausible that the majority of crystallization occurred below these saturation

temperatures. Two-feldspar thermometry of samples PO-5 and PO-6 calculated using the SOLVCALC program (Wen and Nekvasil, 1994; with the thermodynamic models of Nekvasil and Burnham, 1987) at a pressure of $400 \mathrm{MPa}$ produced temperatures of $675^{\circ}$ and $720^{\circ} \mathrm{C}$, respectively. These temperatures are generally consistent with the crystallization of feldspar later than that of zircon in these samples, consistent with textural relations in the samples. The results of two-feldspar geothermometry were fairly insensitive to changes in pressure, increasing or decreasing by only $\sim 20^{\circ} \mathrm{C}$ for pressures of 200 and $600 \mathrm{MPa}$, respectively. In addition, all samples except PO-2 contain tridymite, which is stable only above $\sim 800^{\circ} \mathrm{C}$ with the mineral assemblages found in samples PO-1 to 6 (Figure 12).

Pressures at the time of crystallization are not well determined by geobarometry except in sample PO-2. However, general constraints can be placed on the samples based on the mineral assemblage. As shown in Figure 12, cordierite in sample PO-2 is required

Table 9: Whole-rock zircon saturation temperatures.

\begin{tabular}{|c|c|c|c|c|c|c|}
\hline Sample & PO-1 & PO-2 & PO-3 & PO-4 & PO-5 & PO-6 \\
\hline $\begin{array}{c}\text { Temperature } \\
\left({ }^{\circ} \mathrm{C}\right)\end{array}$ & 874 & 871 & 837 & 848 & 813 & 832 \\
\hline
\end{tabular}


Keller

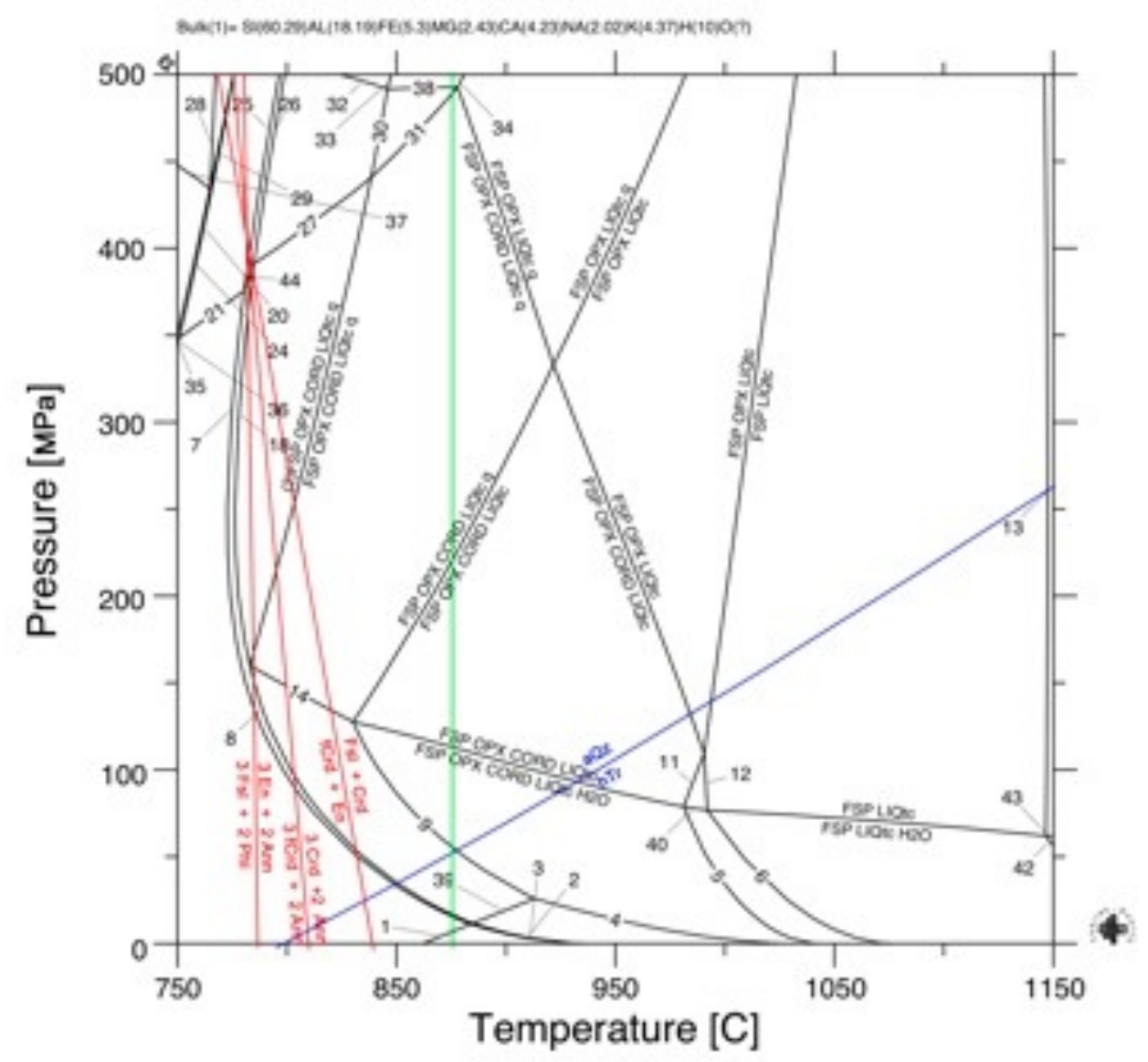

Figure 12: Pressure and temperature constraints on the mineral assemblage of sample PO-2. P-T phase diagram for bulk rock composition of PO-2 calculated using THERIAK-DOMINO software (de Capitani, 1994) with the thermodynamic database of Holland and Powell (1988); phase equilibria for the system annitephlogopite-cordierite-hypersthene (red lines) as well as the quartz-tridymite transition (blue line) plotted with winTWQ (Berman, 2007) using the thermodynamic data of Berman (1988); green line illustrates zircon saturation temperature for sample PO-2. Additional reactions listed in Appendix III.

to have formed below $450 \mathrm{MPa}$, corresponding to depths of $\sim 14 \mathrm{~km}$ or less. Although equilibrium compositions in figure 12 readily shift laterally with variations in water content and bulk composition, the upper limit for cordierite stability is compositionally insensitive, supporting this $450 \mathrm{MPa}$ limit. Equilibrium assemblage calculations on the system biotite + cordierite + hypersthene using the winTWQ software package (Berman, 2007, with thermodynamic data from Berman, 1988) yielded a rough pressure estimate of 
$\sim 400 \mathrm{MPa}$ (Figure 12), as well as a temperature for the assemblage of $780{ }^{\circ} \mathrm{C}$ in $\mathrm{PO}-2$.

\section{Trace Element Geochemistry}

The results of bulk-rock trace element geochemical analysis by X-ray

fluorescence and INAA are shown in Table 10. The data reveal typical arc signatures and extremely steep rare earth patterns, with $\mathrm{Sm} / \mathrm{Yb}$ ratios consistently over 6 and $\mathrm{La} / \mathrm{Yb}$ ratios consistently over 30 (Table 10; Figures 13-16), necessitating the presence of garnet in a high pressure crustal restitic assemblage. Compared to other large-volume AltiplanoPuna ignimbrites in Figure 13, the Frailes volcanics define a field of light rare earth enrichment and extreme heavy rare earth depletion unpopulated by other major

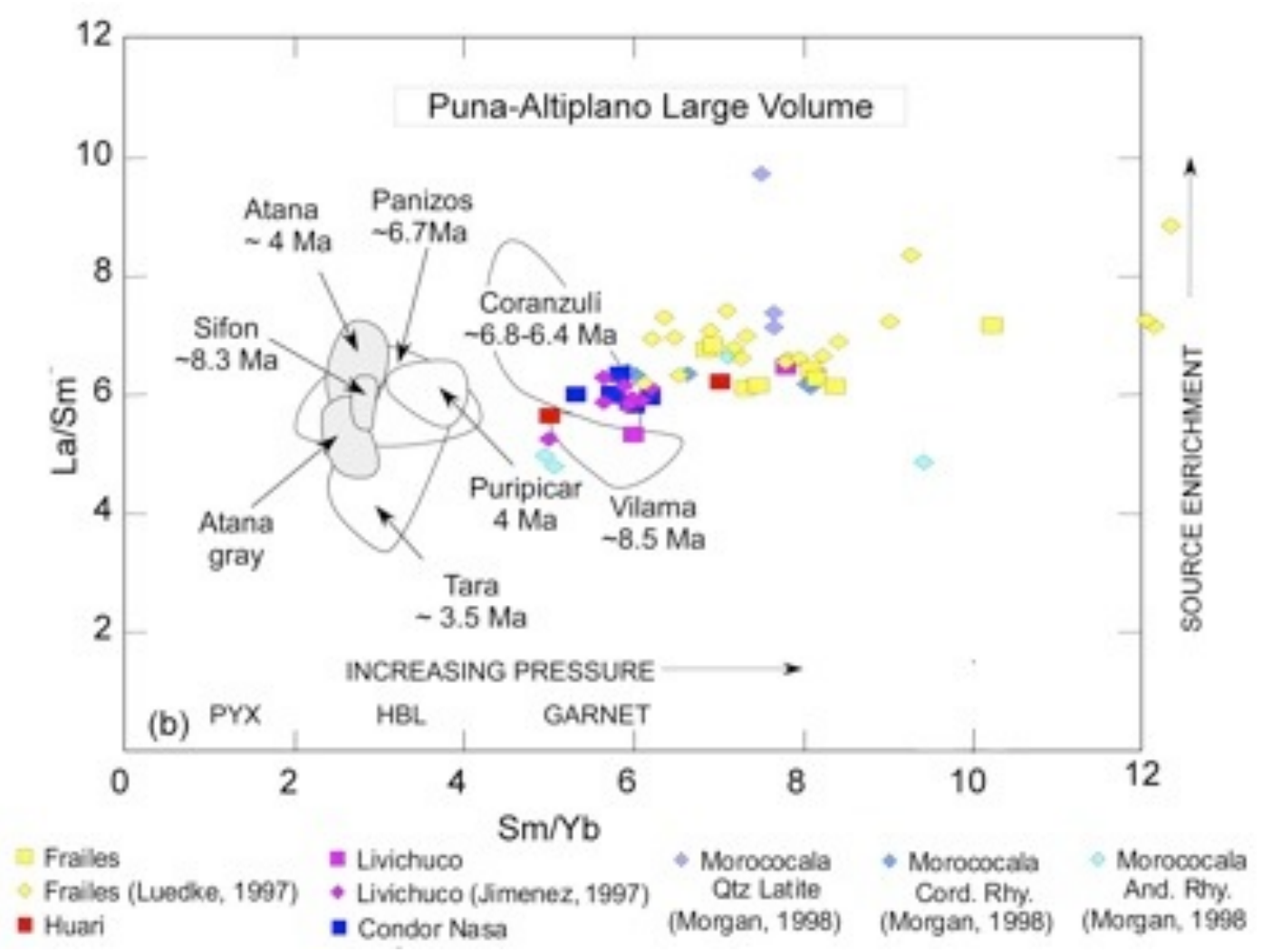

Figure 13: La/Sm versus $\mathrm{Sm} / \mathrm{Yb}$ ratios of large-volume units of the Frailes complex and Morococala ignimbrite in comparison to those of other major Altiplano-Puna ignimbrites (see Figure 2) as compiled in Kay et al, submitted. 
Table 10a: New trace element data from the Porco ignimbrite and comparison to literature values.

\begin{tabular}{|rrrrrrr|}
\hline & \multicolumn{2}{c}{ Porco (this study) } & \multicolumn{3}{c|}{ Porco (Luedke et al., 1997) } \\
\cline { 2 - 7 } $\mathrm{La}$ & PT-1 & PT-2 & PT-3 & P15 & \multicolumn{1}{c|}{ T7 } & T8 \\
\cline { 2 - 7 } $\mathrm{Ce}$ & 63.1 & 73.6 & 93.2 & 98 & 75.2 & 82.0 \\
$\mathrm{Nd}$ & 126.7 & 143.2 & 184.8 & 174 & 130 & 147.8 \\
$\mathrm{Sm}$ & 41.4 & 50.1 & 65.4 & 64.7 & 49.0 & 54.3 \\
$\mathrm{Eu}$ & 7.3 & 8.1 & 11.3 & 11.1 & 8.7 & 9.8 \\
$\mathrm{~Tb}$ & 1.29 & 1.40 & 1.85 & 1.78 & 1.57 & 1.77 \\
$\mathrm{Yb}$ & 0.55 & 0.49 & 0.61 & 0.70 & 0.59 & 0.67 \\
$\mathrm{Lu}$ & 0.82 & 0.73 & 1.07 & 0.95 & 0.95 & 1.18 \\
$\mathrm{Y}$ & 0.11 & 0.10 & 0.18 & 0.12 & 0.11 & 0.14 \\
$\mathrm{Rb}$ & & & & & & \\
$\mathrm{Sr}$ & 466 & 533 & 638 & 670 & 549 & 610 \\
$\mathrm{Ba}$ & 788 & 1006 & 1279 & 930 & 1110 & 928 \\
$\mathrm{Cs}$ & 8.7 & 11.3 & 23.5 & 6.7 & 50.2 & 21.1 \\
$\mathrm{U}$ & 5.5 & 4.8 & 8.4 & 6.1 & 5.3 & 6.3 \\
$\mathrm{Th}$ & 19.2 & 21 & 26.6 & 25.8 & 21.4 & 22.8 \\
$\mathrm{Hf}$ & 3.7 & 4.9 & 6.9 & 6.4 & 5.1 & 6 \\
$\mathrm{Zr}$ & & & & 240 & 205 & 230 \\
$\mathrm{Nb}$ & & & & & 19 & 22 \\
$\mathrm{Ta}$ & 1.29 & 1.47 & 1.74 & 2.34 & 1.48 & 1.68 \\
$\mathrm{Sc}$ & 3.9 & 4.6 & 5.4 & 4.5 & 4.4 & 5.9 \\
$\mathrm{Cr}$ & 11 & 12 & 15 & 8 & 12 & 17 \\
$\mathrm{Ni}$ & & & & & & \\
$\mathrm{Co}$ & 4 & 4 & 5 & & & \\
\hline & & & & & & \\
\hline
\end{tabular}




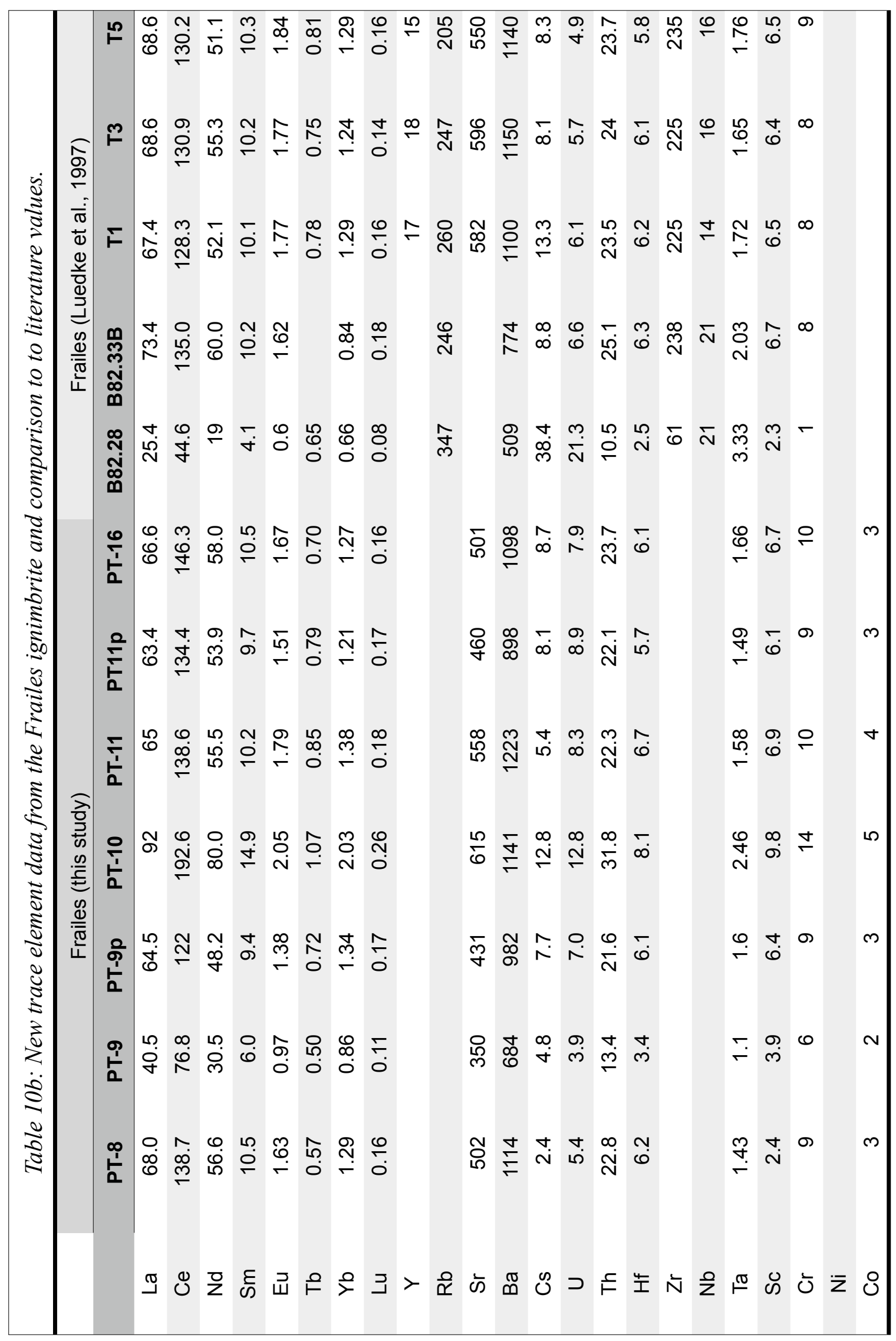


Keller

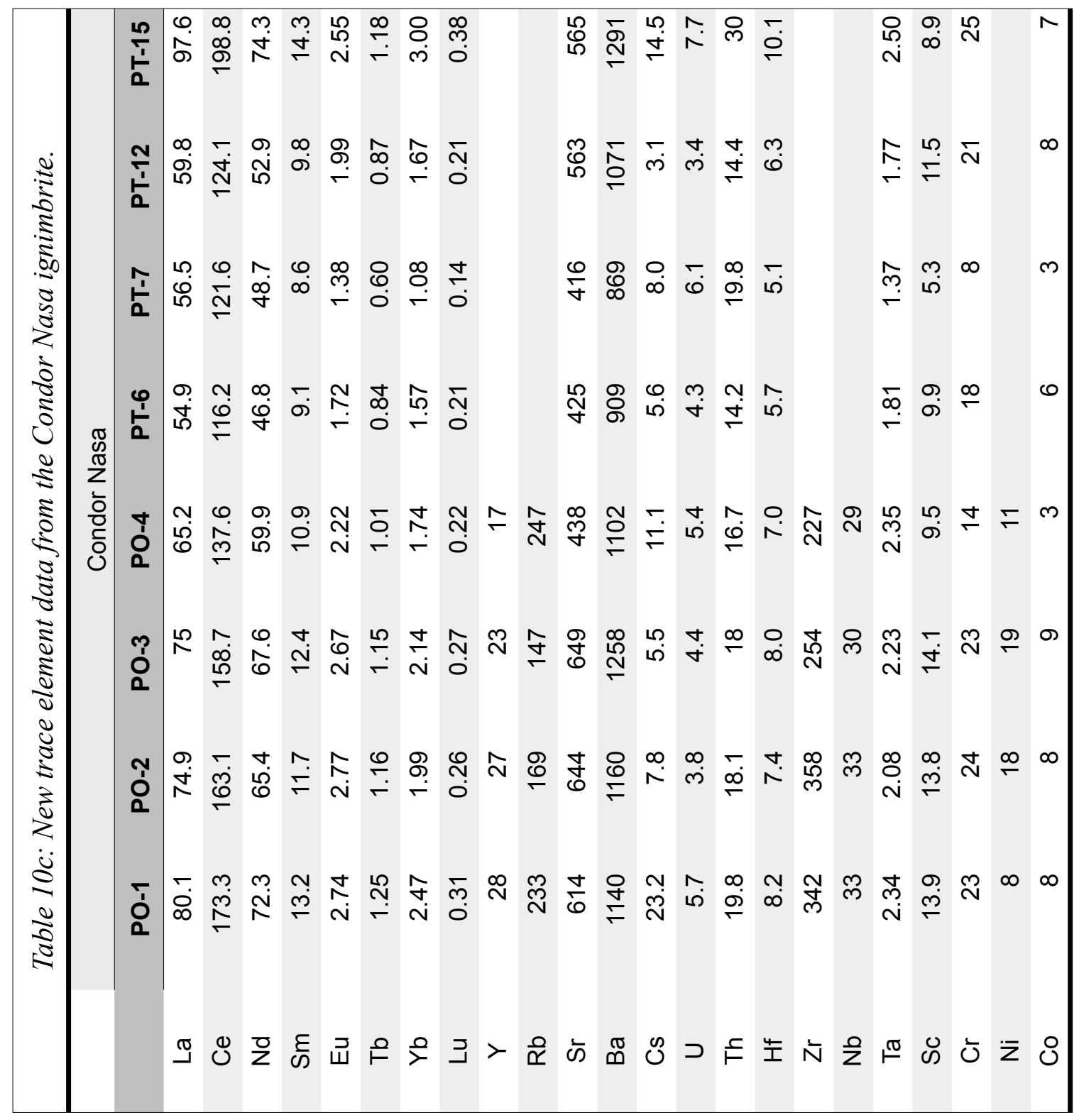




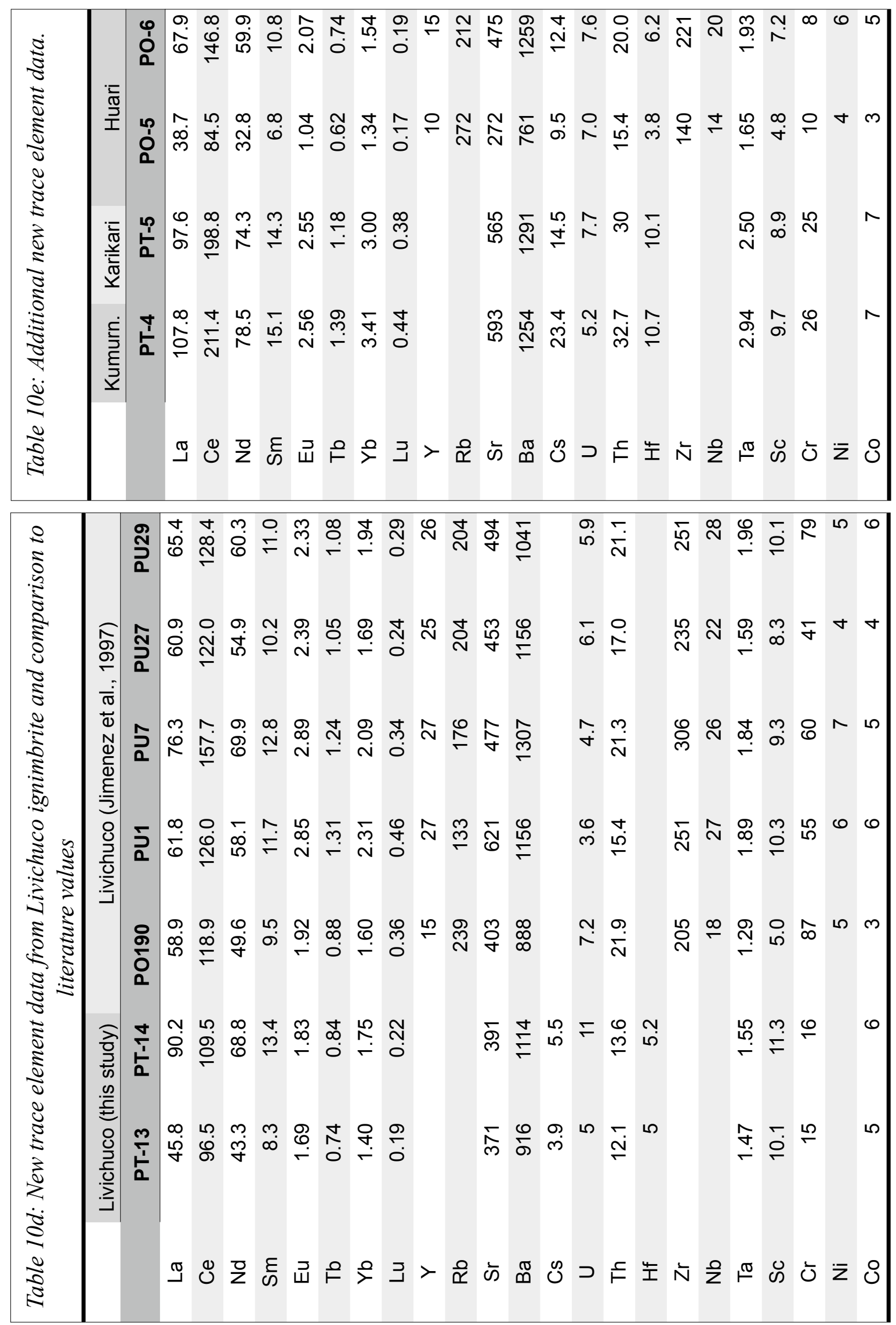




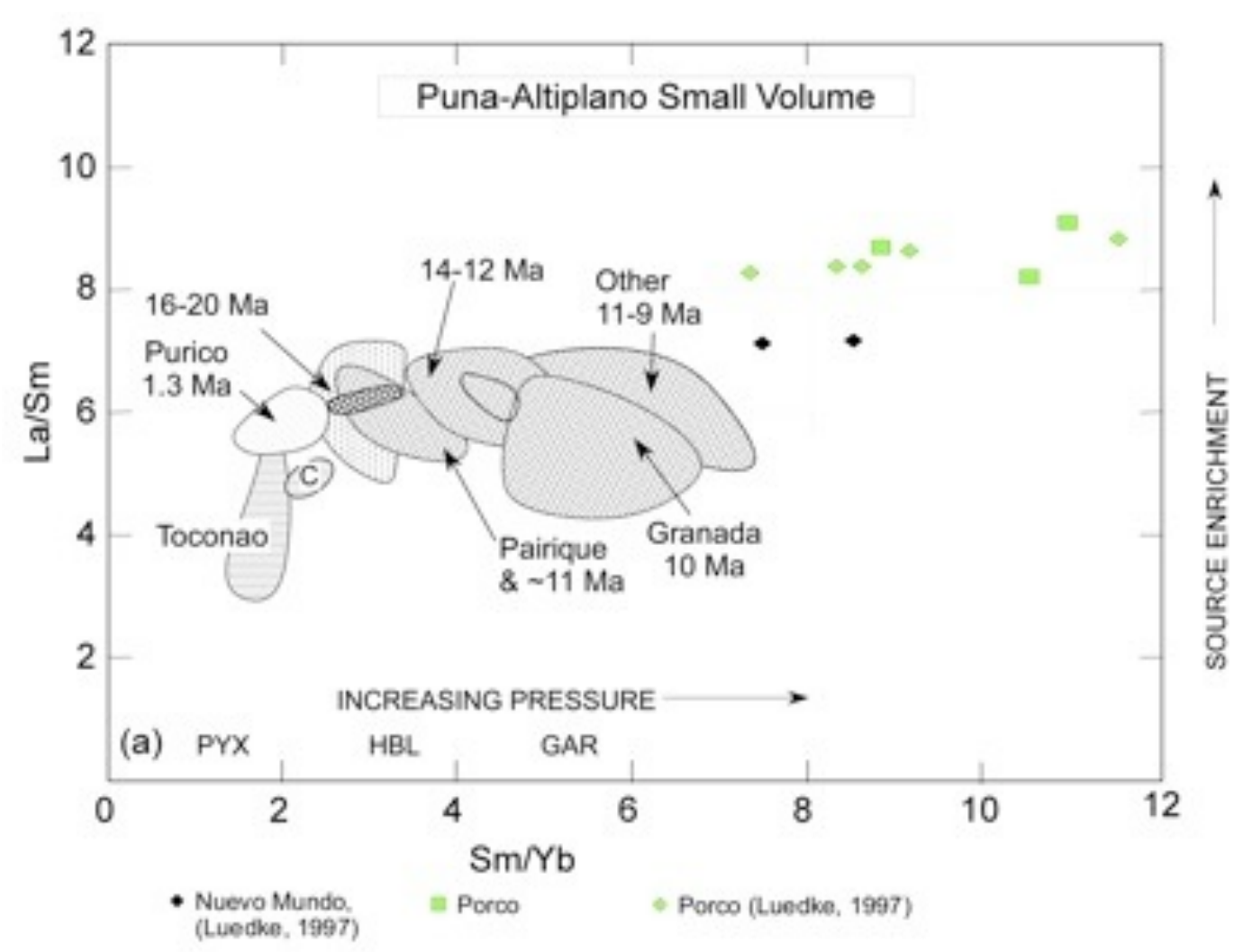

Figure 14: La/Sm versus $\mathrm{Sm} / \mathrm{Yb}$ ratios of small-volume units of the Frailes complex and Morococala ignimbrite in comparison to those of other minor Altiplano-Puna ignimbrites (see Figure 2) as compiled in Kay et al., submitted.

ignimbrite complexes. As Figure 13 illustrates, the main units of the Frailes complex have $\mathrm{La} / \mathrm{Sm}$ ratios of 5 to 9 , and $\mathrm{Sm} / \mathrm{Yb}$ ratios of 5 to 12.5 - values traditionally associated with small ignimbrites derived from low-percentage partial melts. However, at the Frailes complex, the large-volume $\left(\sim 60 \mathrm{~km} * \sim 60 \mathrm{~km} * 300 \mathrm{~m} \approx 1000 \mathrm{~km}^{3}\right)$ main Frailes Meseta falls within this range. Small-volume eruptives at Los Frailes (e.g. Porco) display yet steeper rare earth patterns, with $\mathrm{La} / \mathrm{Sm}$ of 7 to 10 and $\mathrm{Sm} / \mathrm{Yb}$ of 7 to 12 (Figure 14), and La/Yb greater than 100 in some samples from the 14-12 Ma Porco ignimbrite (Table 10).

In addition to steep rare earth fractionation, chondrite- and mantle-normalized multielement diagrams (Figures 15 and 16) illustrate signatures typical of an arc setting, 


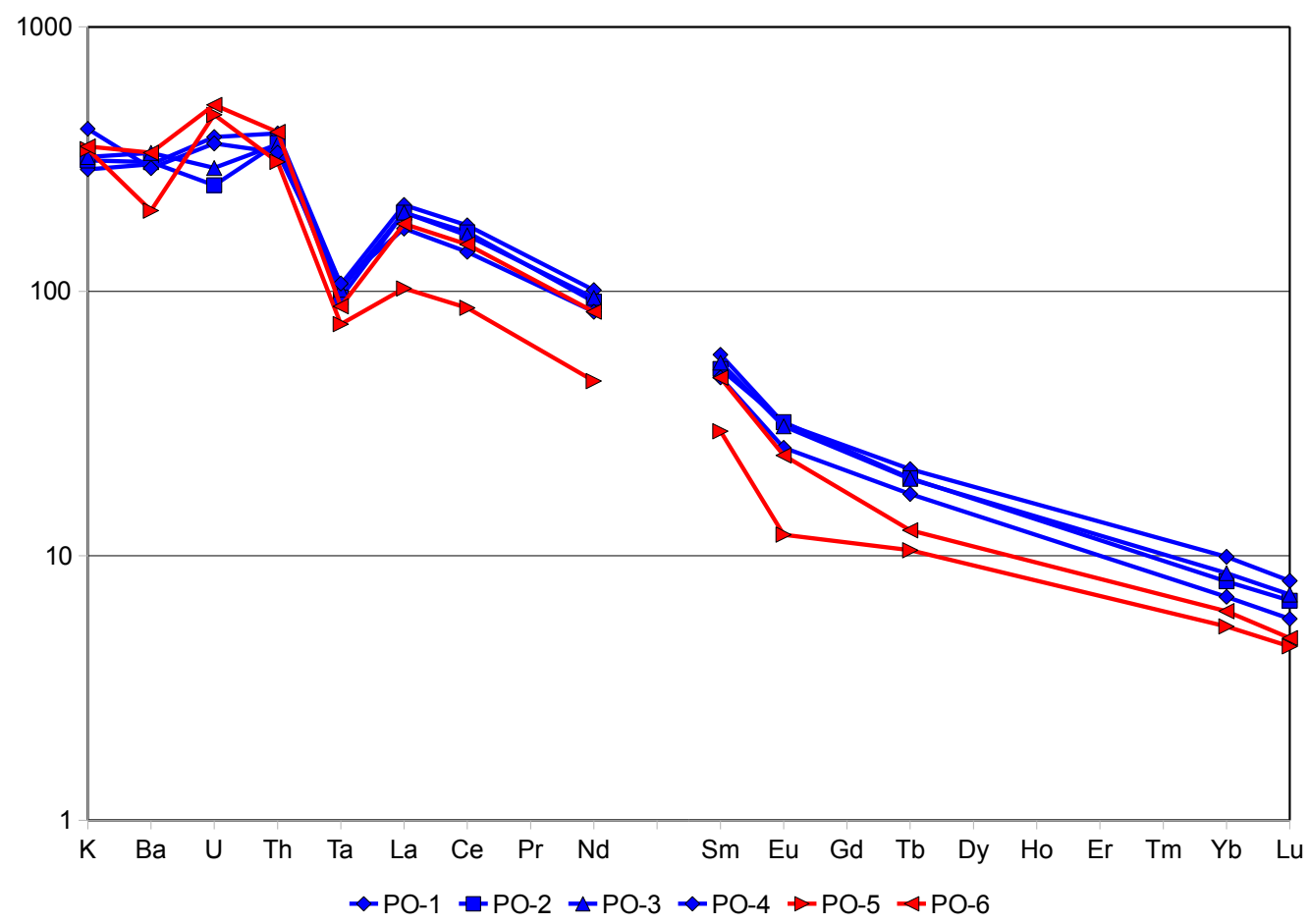

Figure 15: Chondrite-normalized multielement diagram of selected trace and rare earth element concentrations in samples PO-1 to PO-6.

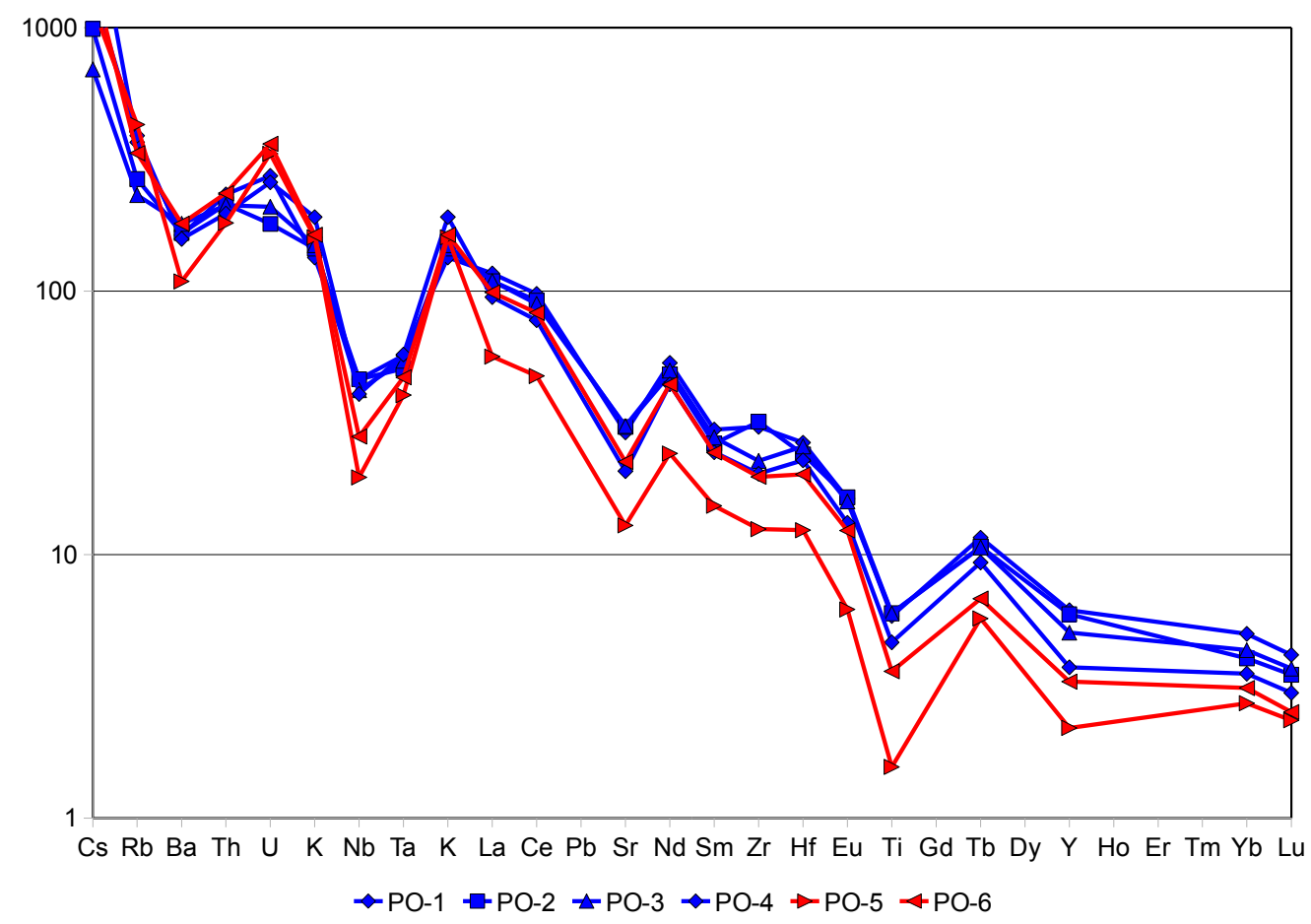

Figure 16: Primitive mantle normalized multielement diagram of trace element concentrations in samples PO-1 to PO-6. 
with depletion of minor-phase comptible high field strength (HFS) elements and enrichment of large-ion lithophile (LIL) elements such as barium relative to the light rareearth elements, conventionally suggesting the influence of arc fluids. Although the Frailes ignimbrites display significant depletion of HFS elements, they exhibit less corresponding enrichment of LIL elements. Europium anomalies are moderate and negative $\left(\mathrm{Eu} / \mathrm{Eu}^{*}\right.$ 0.9-0.6), indicating some fractionation of plagioclase from the melt.

Other, spatially adjacent ignimbrites display similarly steep rare-earth profiles, most notably Morococala $\sim 100 \mathrm{~km}$ to the north (see Figure 2). As determined by Morgan et al. (1998) the Morococala ignimbrite exhibits $\mathrm{La} / \mathrm{Sm}$ ratios near 6 and $\mathrm{Sm} / \mathrm{Yb}$ ratios of 5 to 10 (Figure 13), and plots with the Frailes ignimbrites on multielement diagrams

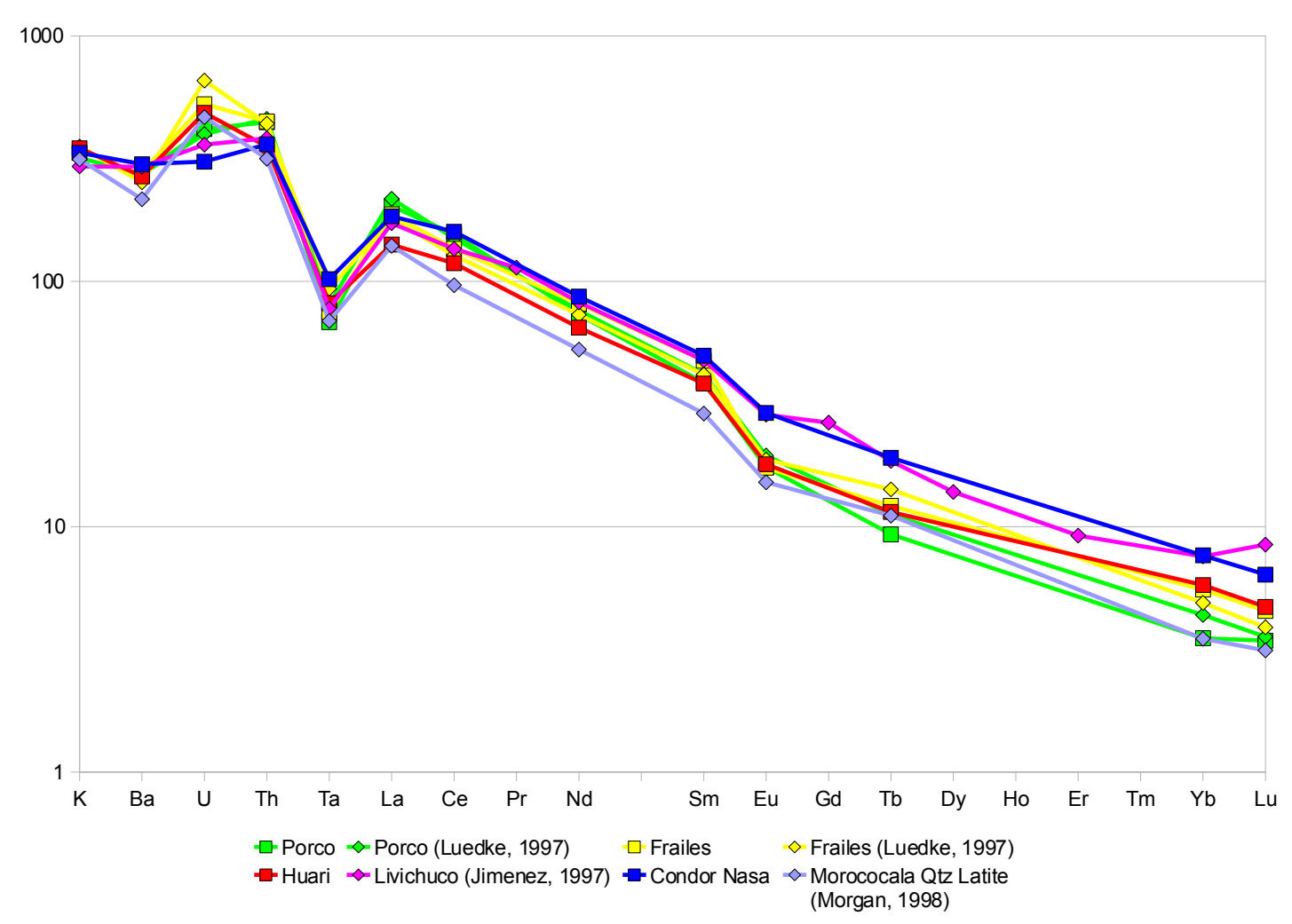

Figure 17: Chondrite-normalized multielement diagram of selected trace and rare earth element concentrations in major units of the Frailes and Morococala ignimbrites. 


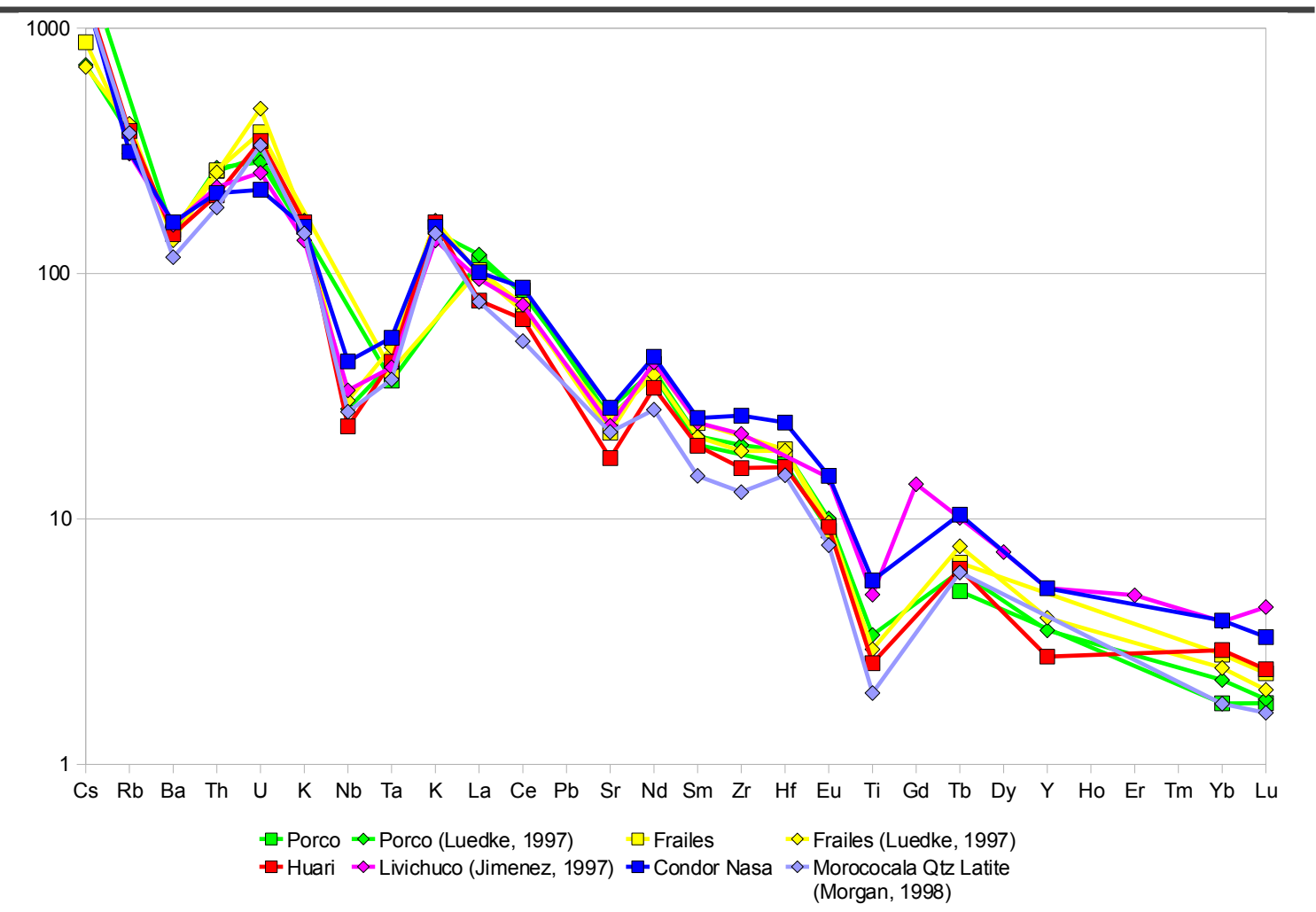

Figure 18: Primitive mantle normalized multielement diagram of trace element concentrations in major units of the Frailes and Morococala ignimbrites.

(Figures 17 and 18). The degree of high field strength element depletion and LIL enrichment are roughly equivalent in samples from Los Frailes and Morococala (Figure 18), reflecting the similarities in the setting of the two ignimbrites.

The peraluminous nature of rocks from the Frailes complex is reflected in Figure 6, with molar $\mathrm{Al}_{2} \mathrm{O}_{3} /\left(\mathrm{CaO}+\mathrm{Na}_{2} \mathrm{O}+\mathrm{K}_{2} \mathrm{O}\right)(\mathrm{Al} / \mathrm{CNK})$ greater than one for all samples, and significantly greater in some silicic samples (for instance 1.28 in sample PO-1). Samples from the Condor Nasa and Livichuco mesetas, while comparatively low in silica, were nevertheless high in Al/CNK (1.1-1.3; Figure 6). As seen in Figure 19, potassium contents in samples from Los Frailes are also high, approaching shoshonitic values, and rising slightly with increasing percent silica. Such potassium content is not unexpected 


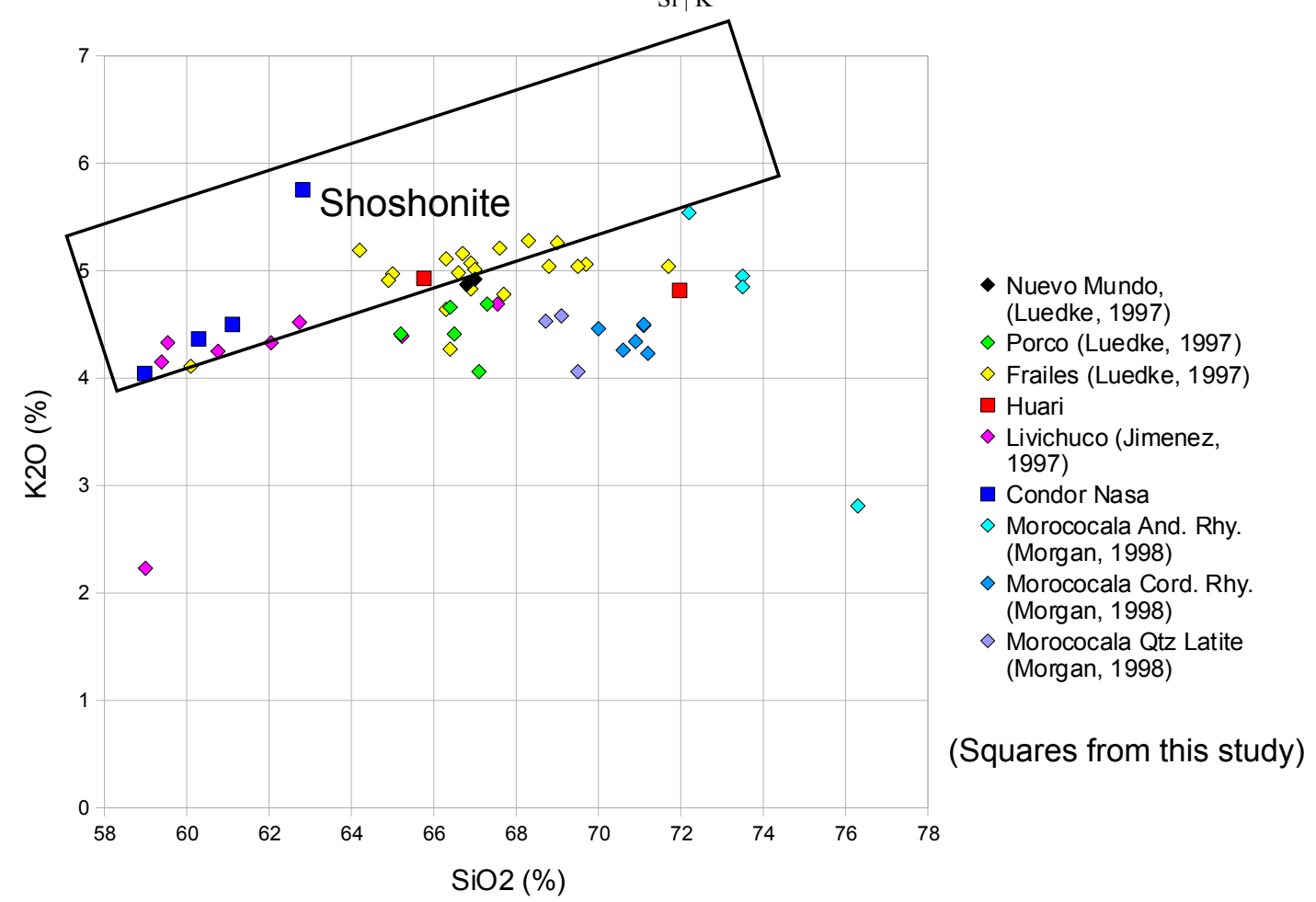

Figure 19: $\mathrm{K}_{2} \mathrm{O}$ versus $\mathrm{SiO}_{2}$ weight percent for representative ignimbrite samples from the Livichuco and Los Frailes ignimbrite complexes.

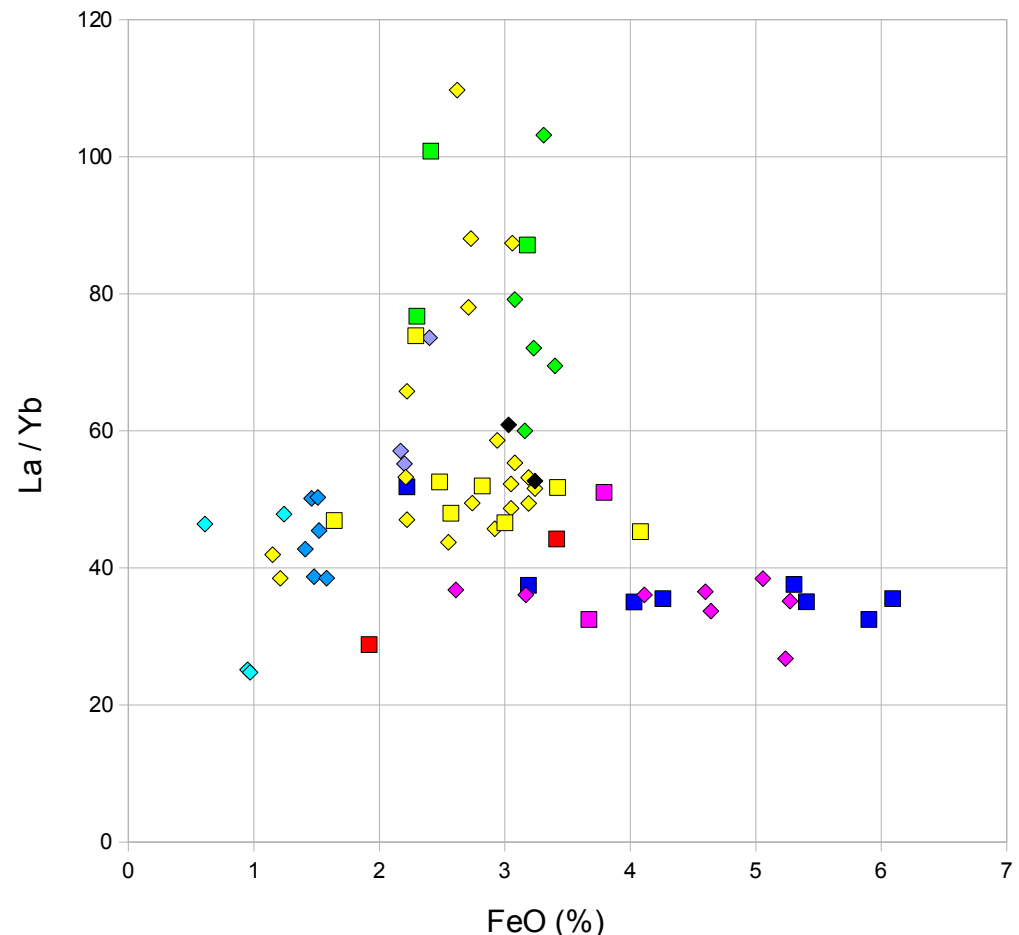

- Nuevo Mundo,

(Luedke, 1997)

$\square$ Porco

$\diamond$ Porco (Luedke, 1997)

$\square$ Frailes

$\diamond$ Frailes (Luedke, 1997)

$\square$ Huari

$\square$ Livichuco

- Livichuco (Jimenez,

1997)

- Condor Nasa

$\diamond$ Morococala And. Rhy. (Morgan, 1998)

$\checkmark$ Morococala Cord. Rhy. (Morgan, 1998)

$\diamond$ Morococala Qtz Latite (Morgan, 1998)

(Squares from this study)

Figure 20: $\mathrm{La} / \mathrm{Yb}$ ratio versus $\mathrm{FeO}$ weight percent for representative ignimbrite samples from the Livichuco and Los Frailes ignimbrite complexes. 
for the back-arc region, given the well-known though simplistic K-h relationship sometimes seen with arc to backarc magmatism (see Kuno, 1959). Notably, La/Yb ratios (Figure 20) are highest for FeO contents of approximately 3\%, showing that high $\mathrm{La} / \mathrm{Yb}$ in samples from the Frailes complex reflects their crustal evolution as well as the mantle influence.

$\mathrm{Ba} / \mathrm{Ta}$ and $\mathrm{La} / \mathrm{Ta}$ ratios, shown in Figure 21, tend to plot with $\mathrm{Ba} / \mathrm{La}$ slopes between 10 and 20, lower than values seen in a main arc setting but in line with those expected for back-arc volcanism and seen in other Puna-Altiplano backarc ignimbrites (Coira et al., 1993; Kay et al., 1999; Kay et al., submitted). Samples from the Frailes and Morococala complexes that plot with low absolute $\mathrm{Ba}$ and La contents are those with

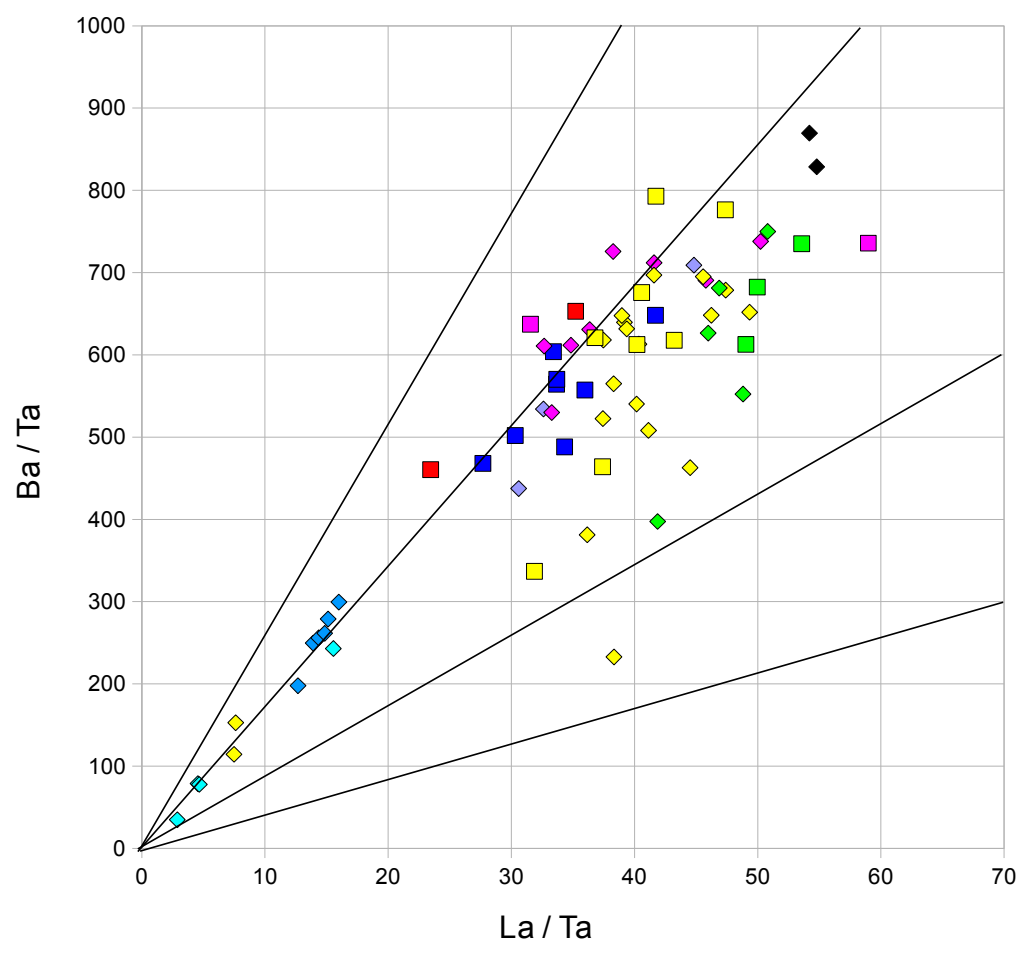

- Nuevo Mundo, (Luedke, 1997)

$\square$ Porco

$\diamond$ Porco (Luedke, 1997)

$\square$ Frailes

$\diamond$ Frailes (Luedke, 1997)

$\square$ Huari

$\square$ Livichuco

$\diamond$ Livichuco (Jimenez, 1997)

- Condor Nasa

$\diamond$ Morococala And. Rhy. (Morgan, 1998)

- Morococala Cord. Rhy. (Morgan, 1998)

$\diamond$ Morococala Qtz Latite (Morgan, 1998)

(Squares from this study)

Figure 21: Ba/Ta versus La/Ta ratios of representative ignimbrite samples from the Livichuco and Los Frailes ignimbrite complexes. Diagonal lines represent Ba/ La ratios of 5, 10, 20, and 30 . 
Keller

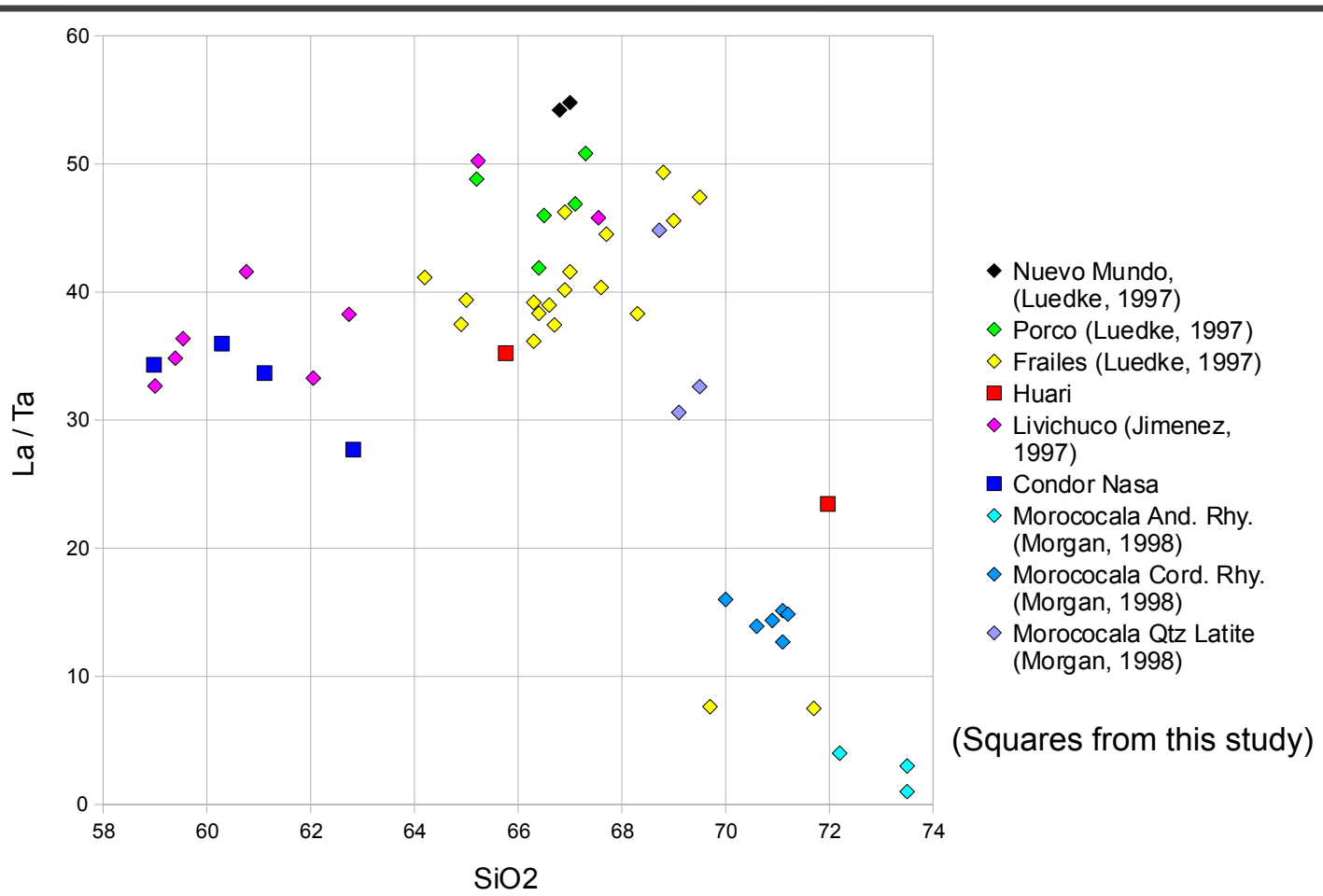

Figure 22: La/Ta ratio versus $\mathrm{SiO}_{2}$ weight percent for representative ignimbrite samples from the Livichuco and Los Frailes ignimbrite complexes.

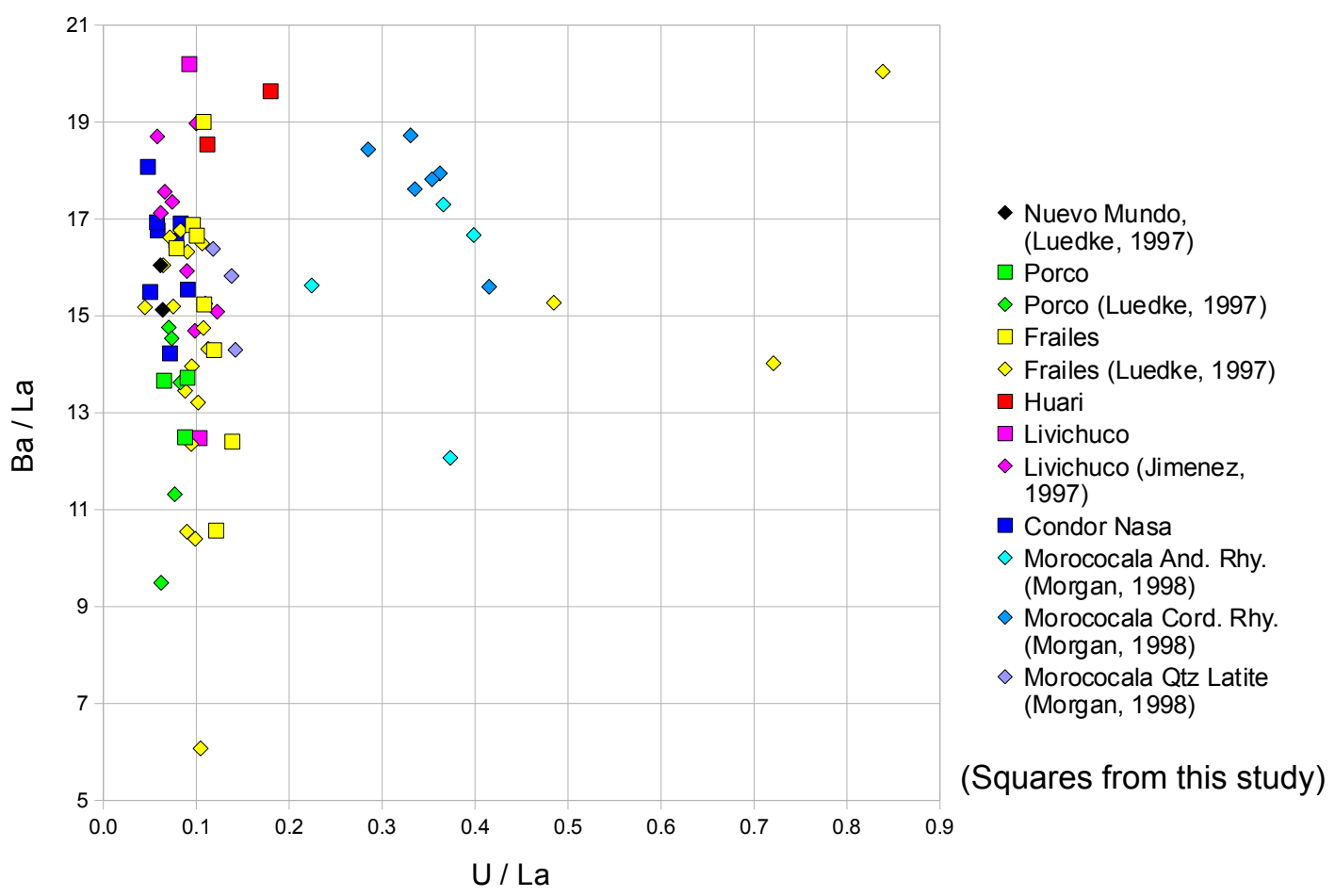

Figure 23: Ba/La versus U/La ratios of representative ignimbrite samples from the Livichuco and Los Frailes ignimbrite complexes. 
high silica and low La/Ta ratios in Figure 22; the presence of Ta- and Ba-bearing phases at higher percent silica may be responsible for this trend. As seen in Figure 23, most samples fall near a $\mathrm{U} / \mathrm{La}$ ratio of 0.1 ; however, outliers with much higher uranium content are present. In general, samples with anomalously high uranium content tend to be rich in barium as well, reflecting the similar solubilities of the ions under reduced conditions.

\section{Discussion}

The mineralogical and geochemical data from Los Frailes recount a clear history of melt creation and evolution, from production of melt at the base of the crust through transport, fractionation, and eruption at the surface. Extreme depletion of heavy rare earth elements demonstrates the presence of garnet in the restitic assemblage, whereas enrichment of light rare earths records melt evolution and fractionation. As is well known, the stability field of garnet in the crust necessitates that for garnet to be present in the restitic assemblage, fractionation must occur at high pressures, corresponding to the lower levels of a thick crust. Crustal thicknesses beneath the Frailes region are considered to be $\sim 65 \mathrm{~km}$ based on seismological imaging (Beck et al., 1996; Yuan et al., 2002; McGlashan et al., 2008) beneath the Frailes complex. At the same time, the mineral assemblage of the Frailes samples, including plagioclase and cordierite, records low pressures - less than $450 \mathrm{MPa}$ for cordierite-bearing samples, corresponding to depths in the less than $14 \mathrm{~km}$ in the mid to upper crust (Figure 24). Consequently, it can be reasonably concluded that the Frailes magmas underwent two periods of ponding or storage at distinct depths: first, at the base of the crust, as mantle-derived melts ponded at the base of the crust, fractionating a garnet-bearing restitic assemblage; and second, at 


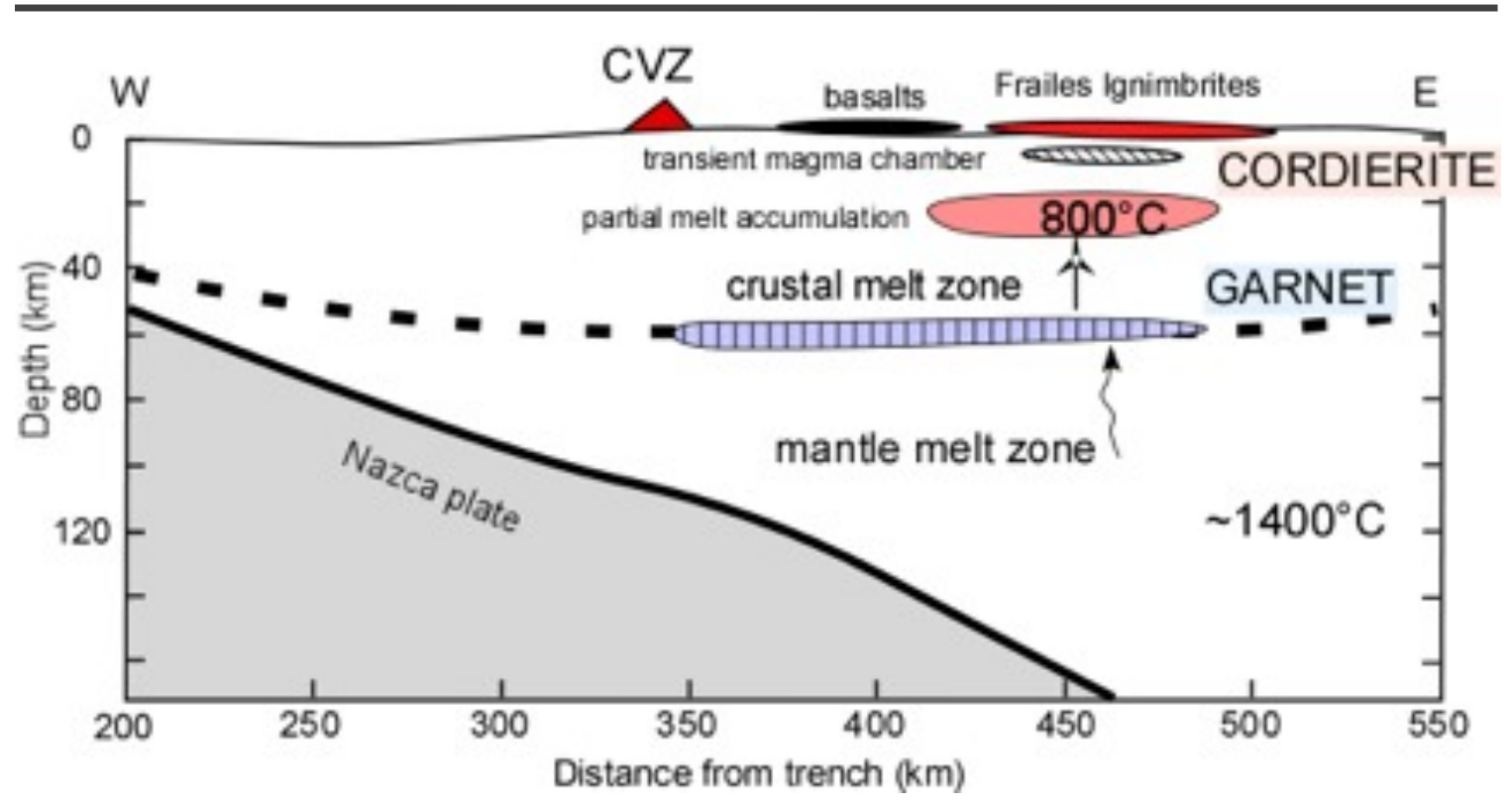

Figure 24: Lithospheric-scale diagrammatic cross-section of the Frailes region. Adapted from Kay et al., submitted.

mid to upper crustal depths, as the ascending and magma accumulated and further fractionated in crustal magma chambers.

Geochemical data also indirectly shed light on the age of the central Frailes Meseta. Sample PT-11 was collected from the same location as Barke et al. (2007) sample G1, dated by Ar-Ar techniques on biotite at $2.24 \pm 0.09 \mathrm{Ma}$ (See Figure 5). As seen in Table 11, INAA data show that the samples from the dated locality falls within the range of compositions seen in Luedke's (1997) samples from the south of the main ignimbrite $\sim 40 \mathrm{~km}$ away (Figure 3), consistent with the interpretation that this age is representative of the whole of the Frailes Meseta ignimbrite. This, combined with a yet younger biotite Ar/Ar age of 1.86 \pm 0.09 Ma recorded by Barke et al. (2007) on sample YURb approximately $60 \mathrm{~km}$ to the south (Figure 5), is strong evidence for an $\sim 2 \mathrm{Ma}$ age for the central Frailes volcanics. Due to the size of the Frailes meseta, a reassessment of the age of this massif significantly changes the eruptive history of the complex: with the 
main meseta covering and area of roughly $3600 \mathrm{~km}^{3}$, it makes up roughly half of the Frailes complex and involves the eruption of a massive amount of volcanic material in a short time span, requiring a very large input of heat to the crust at this time.

If the central Frailes Meseta of the ignimbrite complex is indeed of $\sim 2 \mathrm{Ma}$ provenance, a more coherent picture of volcanism at the Frailes complex begins to take form. Recent volcanism, the current-day presence of crustal and mantle low-velocity anomalies, and steep rare-earth fractionation from a high-pressure resititic assemblage are all consistent with a history of delamination-induced magmatism. This process, as detailed in the context of the Altiplano-Puna plateau by Kay et al. (1994) and Kay and Coira (2009), is triggered by foundering of high-density material from the base of orogenically thickened crust. Influx of hot asthenospheric mantle to fill the place of the foundered mass creates the mantle low-velocity anomaly observed in the geophysical images of Myers et al. (1998) and Beck and Zandt (2002) (Figure 4); decompression melting of the asthenosphere produces mantle-derived basalt, which ponds at the base of the crust, producing the garnet fractionation seen in the rare earth element ratios; and the large volume further of basalt produced by such a process provides way to produce the huge volumes of magma erupted at the surface, after further evolution of the melt and interaction with the crust (Figure 24).

\section{Conclusion}

The Frailes ignimbrite complex fills a gap in the understanding of large-volume ignimbrites of the Altiplano-Puna plateau. As the largest and most prominent ignimbrite of the Andean Central Volcanic Zone, the complex supplies insight into the processes of large-volume silicic melt formation in a back-arc setting. Trace element analyses 
demonstrate the presence of garnet in a deep-crustal, high-pressure restitic assemblage, while the presence of cordierite in the phenocryst assemblage indicates crystallization at low pressure. The geochemical data from the complex suggest a history of melt formation at depth in the upper mantle, the formation of residual garnet at the base of the crust, and evolution and crystallization of the melt at upper crustal levels. In a back-arc setting, these characteristics along with the large volume of the Frailes ignimbrite and geochemical and geochronological data are most compatible with recent delamination and delamination-induced magmatism.

\section{Acknowledgements}

Many individuals contributed to the research reported this paper, foremost among them my advisor, Professor Suzanne Mahlburg Kay, without whom the project would not have been possible. Invaluable guidance in fieldwork and interpretation was provided by Beatriz L. Coira (Jujuy), Pablo J. Caffe (Jujuy), and Nestor Jimenez (La Paz). Chelsea Allison (Cornell) also assisted in the field and is conducting Sr isotopic analyses on a selection of these samples. Professor Robert W. Kay (Cornell) provided important discussion as well as much assistance with neutron activation analysis. X-ray fluorescence analyses were provided by Professor Beatriz Coira in Jujuy. In addition, I would like to acknowledge John Hunt (Cornell) for assistance with the electron microprobe as well as Professor Christopher Andronicos (Cornell) for valuable discussion. This manuscript benefited substantially from constructive reviews by Professors Suzanne Mahlburg Kay and Robert W. Kay. Funding was provided by the Cornell University Department of Earth and Atmospheric Sciences undergraduate field 
studies account and by a Morley Student Research Grant from the Cornell University College of Agriculture and Life Sciences. 


\section{References}

Baker, M.C.W. and Francis, P.W. (1978). Upper Cenozoic volcanism in the central Andes, ages and volumes. Earth and Planetary Science Letters 41, 175-187.

Barke, R, Lamb, S. and MacNiocaill, C. (2007). Late Cenozoic bending of the Bolivian Andes: New paleomagnetic and kinematic constraints, Journal of Geophysical Research 12, B01101.

Beck, S. and Zandt, G. (2002). The nature of orogenic crust in the central Andes, Journal of Geophysical Research 107(B10), 2230.

Beck, S., Zandt G., Myers, S., Wallace, T., Silver, P., and Drake, L. (1996). Crustal thickness variations in the central Andes, Geology 24, 407-410.

Berman, R.G. (1988). Internally-consistent thermodynamic data for minerals in the system Na2O-K2O-CaO-MgO-FeO-Fe2O3-A12O3-SiO2-TiO2-H2O-CO2. Journal of Petrology 29, 445-522

Berman, R.G. (2007). winTWQ (version 2.3): a software package for performing internally-consistent thermobarometric calculations. Geological Survey of Canada, Open File 5462, ed. 2.32, 41 p.

Caffe, P.J., Trumbull, R.B., Coira, B.L., Romer, R.L. (2002). Petrogenesis of early Neogene magmatism in the northern Puna; implications for magma genesis and crustal processes in the Central Andean plateau. Journal of Petrology 43, 907-942.

Cahill, T. A. and Isacks, B. L. (1992). Seismicity and shape of the subducted Nazca Plate. Journal of Geophysical Research 97, 17503-17529. 
Coira, B.L., Kay, S.M., Viramonte, J. (1993). Upper Cenozoic magmatic evolution of the Argentine Puna - A model for changing subduction geometry. International Geology Review 35, 677-720.

Davidson, J.P. and de Silva, S.L. (1995). Late Cenozoic magmatism of the Bolivian Altiplano. Contributions to Mineralogy and Petrology 119, 387-408.

de Capitani C. (1994). Gleichgewichts-Phasendiagramme: Theorie und Software. Beihefte zum European Journal of Mineralogy, 72. Jahrestagung der Deutschen Mineralogischen Gesellschaft 6, 48.

de Silva, S.L. and Gosnold ,W.D. (2007). Episodic construction of batholiths: Insights from the spatiotemporal development of an ignimbrite flare-up. Journal of Volcanology and Geothermal Research 167, 320-325.

Evernden, J.F., Kriz, S.J., and Cherroni, C. (1977). Potassium-argon ages of some Bolivian rocks, Economic Geology 72, 1042-1061.

Hoke, L. and Lamb, S. (2008). Cenozoic behind-arc volcanism in the Bolivian Andes, South America: implications for mantle melt generation and lithospheric structure. Journal of the Geological Society of London 164, 705-814.

Holland, T.J.B. and Powell, R. (1998). An internally-consistent thermodynamic dataset for phases of petrological interest. Journal of Metamorphic Geology 16, 309-344.

Jimenez, N., Arando, G. and Almendras, O. (1997), Estructura, evolución y petrología del complejo volcánico de Livichuco, norte de la meseta de los Frailes, Boletín del Servicio Nacional de Geología y Minería 23, 37-59. 
Kay, S.M., Coira, B., Viramonte, J. (1994). Young mafic back-arc volcanic rocks as indicators of continental lithospheric delamination beneath the Argentine Puna plateau, Central Andes. Journal of Geophysical Research 99, 24323-24339.

Kay, S.M., Mpodozis, C., and Coira, B.L. (1999). Magmatism, tectonism and mineral deposits of the central Andes ( $22^{\circ}-33^{\circ} \mathrm{S}$ latitude). In Skinner BJ (ed.), Geology and ore deposits of the central Andes, Society of Economic Geol. Special Publication 7, 27-59.

Kay, S.M. and Coira, B.L. (2009) Shallowing and steepening subduction zones, continental lithospheric loss, magmatism and crustal flow under the central Andean Altiplano-Puna plateau. In Kay SM, Ramos VA, Dickinson WR (eds) Backbone of the Americas: Shallow subduction, plateau uplift and ridge and terrane collision, Geol. Soc. Am. Memoir 204.

Kay, S.M., Coira, B.L., Caffe, B.L. and Chen, C. Submitted. Regional chemical diversity, crustal and mantle sources and evolution of the Puna Plateau ignimbrites in the Central Andes. Journal of Volcanology and Geothermal Research

Kennan, L., Lamb, S.H., and Rundle, C. (1995). K-Ar dates from the Altiplano and Cordillera Oriental of Bolivia: Implications for Cenozoic stratigraphy and tectonics, J. S. Am. Earth Sci. 8, 163-186.

Kuno, H. (1959). Origin of Cenozoic petrographic provinces of Japan and surrounding areas. Bulletin of Volcanology 20, 37-76.

Lehmann, B., Ishihara, S., Michel, H., Miller, J., Rapela, C.W., Sanchez, A., Tistl, A.M., and Winkelmann, L. (1990). The Bolivian tin province and regional tin 
distribution in the Central Andes; a reassessment. Economic Geology 85(5), 1044-1058.

Luedke, R.G, Ericksen, G.E., Urquidi b., Tavera V., F., Smith, R.L., and Cunningham, C.G. (1997). Geochemistry of peraluminous volcanic rocks along the southern margin of the Los Frailes volcanic field, central Bolivian tin belt, Boletín del Servicio Nacional de Geología y Minería 23, 14-36.

McGlashan, N., Brown, L.D., Kay, S.M. (2008). Crustal thicknesses in the Central Andes from teleseismically recorded depth phase precursors. Geophysical Journal International 175, 1013-1022.

Morgan IV, G.B., London, D., Luedke, R. (1998). Petrochemistry of Late Miocene peraluminous silicic volcanic rocks from the Morococala field, Bolivia. Journal of Petrology 39(4), 601-632.

Myers, S. C., Beck, S., Zandt, G. and Wallace, T. (1998). Lithospheric-scale structure across the Bolivian Andes from tomographic images of velocity and attenuation for P and S waves. Journal of Geophysical Research 103, 21233-21252.

Nekvasil, H. and Burnham, C.W. (1987). The calculated individual effects of pressure and water content on phase equilibria in the granite system, in Myesn, B.O., ed. Magmatic Processes: Physiochemical Principles. Geochemical Society, University Park, PA.

Rice, C.M, Steele, G.B., Barfod, D.N., Boyce, A.J., and Pringle, M.S. (2005) Duration of magmatic, hydrothermal, and supergene activity at Cerro Rico de Potosi, Bolivia Economic Geology 100(8), 1647-1656. 
Risse, A., Trumbull, R.B., Coira, B., Kay, S.M., and van den Bogaard, P. (2008). 40Ar/ 39Ar geochronology of basaltic volcanism in the back-arc region of the southern Puna plateau, Argentina. Journal of South American Earth Sciences 26, 1-15. Schneider, A. (1985). Eruptive processes, mineralization and isotopic evolution of the Los Frailes - KariKari region, Boliva. PhD. Thesis, Imperial College of Science and Technology, University of London, 295 pp.

Schneider, A. and Halls, C. (1985). Chronology of eruptive processes and mineralization of the Frailes Karikari volcanic field, Eastern Cordillera, Bolivia.

Comunicaciones, Departamento de Geología, Universidad de Chile 35, 217-224.

Schneider, A. (1987). Eruptive processes, mineralization and isotopic evolution of the Los Frailes - Kari Kari Region, Bolivia. Rev. Geol. de Chile 30, 27-33.

Watson, E.B. and Harrison, T.M. (1983). Zircon saturation revisited: temperature and composition effects in a variety of crustal magma types. Earth and Planetary Science Letters 64, 295-304.

Wen, S.and Nekvasil, H. (1994). SOLVCALC: An interactive graphics program package for calculating the ternary feldspar solvus and for two-feldspar geothermometry. Computers \& Geosciences 20(6), 1025-1040.

Yuan, X., Sobolev, S. V. and Kind, R. (2002). Moho topography in the central Andes and its geodynamic implications. Earth and Planetary Science Letters 199, 389-402. 


\section{Appendix}

\begin{tabular}{|l|c|c|c|c|c|c|}
\hline \multicolumn{5}{|c|}{ Appendix I: Standards used for neutron activation analysis. } \\
\hline & \multicolumn{3}{|c|}{ Known values } & \multicolumn{3}{c|}{ This study (run 1) } \\
\hline & WBD & PAL & SIT & WBD & PAL & SIT \\
\hline FeO & 9.59 & 10.15 & 4.34 & 9.59 & 10.15 & 4.34 \\
\hline Na2O & 0.11 & 2.07 & 5.30 & 0.1 & 2.06 & 5.30 \\
\hline La & 82.9 & 10.5 & 14.6 & 82.9 & 10.2 & 13.7 \\
\hline Ce & 158.0 & 23.6 & 33.8 & 158.0 & 23.9 & 33.2 \\
\hline Nd & 58.0 & 13.0 & 18.3 & 58.0 & 12.8 & 18.7 \\
\hline Sm & 8.23 & 3.42 & 4.68 & 8.23 & 39.55 & 4.69 \\
\hline Eu & 2.14 & 1.07 & 1.09 & 2.14 & 1.11 & 1.03 \\
\hline Tb & 0.620 & 0.67 & 0.760 & 0.617 & 0.67 & 0.732 \\
\hline Yb & 0.610 & 2.18 & 3.42 & 0.673 & 2.18 & 3.48 \\
\hline Lu & 0.085 & 0.3 & 0.500 & 0.085 & 0.3 & 0.501 \\
\hline Sr & & 183 & 255 & 478 & 202 & 255 \\
\hline Ba & 1280 & 185 & 935 & 1159 & 182 & 935 \\
\hline Cs & 1.81 & 2.19 & 1.25 & 1.81 & 2.06 & 1.43 \\
\hline U & 2.35 & 0.497 & 2.58 & 2.35 & 0.479 & 2.52 \\
\hline Th & 11.00 & 2.07 & 5.26 & 11.00 & 1.99 & 5.11 \\
\hline Hf & 3.92 & 2.56 & 4.61 & 3.92 & 2.66 & 4.7 \\
\hline Ta & 8.30 & 0.65 & 0.54 & 8.30 & 0.65 & 0.61 \\
\hline Sc & 20.2 & 37.5 & 9.25 & 20.2 & 39.5 & 9.6 \\
\hline Cr & 1910 & 314 & 2 & 1910 & 309 & 1 \\
\hline Ni & 991 & 89 & 2 & 991 & 89 & 6 \\
\hline Co & 88 & 53 & 36 & 88 & 53 & 26 \\
\hline
\end{tabular}




\begin{tabular}{|c|c|c|c|c|c|}
\hline \multicolumn{6}{|c|}{ Appendix II: standards used in electron probe microanalysis. } \\
\hline \multicolumn{6}{|c|}{ Known Values } \\
\hline & Px1 & S-15 & A 99 & JdF & Kak \\
\hline $\mathrm{SiO2}$ & 53.94 & 39.69 & 50.94 & 50.81 & 40.37 \\
\hline TiO2 & 0.26 & 4.27 & 4.06 & 1.85 & 4.72 \\
\hline $\mathrm{Al} 2 \mathrm{O3}$ & 0.66 & 14.37 & 12.49 & 14.06 & 14.90 \\
\hline $\mathrm{FeO}$ & 2.93 & 10.74 & 13.32 & 11.83 & 10.92 \\
\hline MnO & 0.07 & 0.09 & 0.19 & 0.22 & 0.09 \\
\hline MgO & 16.93 & 13.28 & 5.08 & 6.71 & 12.80 \\
\hline $\mathrm{CaO}$ & 24.55 & 11.58 & 9.30 & 11.12 & 10.30 \\
\hline $\mathrm{Na} 2 \mathrm{O}$ & 0.24 & 2.12 & 2.66 & 2.62 & 2.60 \\
\hline K2O & 0.01 & 1.96 & 0.82 & 0.19 & 2.05 \\
\hline Total & 99.59 & 98.10 & 98.86 & 99.41 & 98.75 \\
\hline \multicolumn{6}{|c|}{ This study } \\
\hline & Px1 & S-15 & A 99 & JdF & Kak \\
\hline $\mathrm{SiO} 2$ & 54.55 & 40.05 & 51.1 & 50.36 & 40.24 \\
\hline TiO2 & 0.23 & 4.41 & 4.06 & 1.85 & 4.85 \\
\hline Al2O3 & 0.66 & 14.56 & 12.45 & 14.07 & 14.24 \\
\hline $\mathrm{FeO}$ & 2.87 & 9.92 & 13.43 & 11.76 & 10.79 \\
\hline MnO & 0.07 & 0.08 & 0.18 & 0.19 & 0.09 \\
\hline $\mathrm{MgO}$ & 16.99 & 13.53 & 5.06 & 6.87 & 12.64 \\
\hline $\mathrm{CaO}$ & 24.92 & 11.55 & 9.26 & 11.02 & 10.15 \\
\hline $\mathrm{Na2O}$ & 0.22 & 2.37 & 2.91 & 2.85 & 2.65 \\
\hline K2O & 0 & 2.1 & 0.84 & 0.19 & 2.09 \\
\hline Total & 100.51 & 98.56 & 99.31 & 99.17 & 97.73 \\
\hline
\end{tabular}


Appendix III: Key to reactions shown in Figure 12.

1): (2)FSP OPX CORD q H2O = (2)FSP OPX CORD trd H2O

2): (2)FSP OPX CORD trd $\mathrm{H} 2 \mathrm{O}=(2) \mathrm{FSP}$ OPX CORD LIQtc trd $\mathrm{H} 2 \mathrm{O}$

3): (2)FSP OPX CORD LIQtc trd $\mathrm{H} 2 \mathrm{O}=\mathrm{FSP}$ OPX CORD LIQtc trd $\mathrm{H} 2 \mathrm{O}$

4): FSP OPX CORD LIQtc trd H2O = FSP OPX CORD LIQtc H2O

5): FSP OPX CORD LIQtc H2O = FSP CORD LIQtc H2O

6): FSP CORD LIQtc H2O = FSP LIQtc H2O

7): (2)FSP OPX CORD LIQtc q H2O = (2)FSP OPX CORD q H2O

8): (2)FSP OPX CORD LIQtc q H2O = FSP OPX CORD LIQtc q H2O

9): FSP OPX CORD LIQtc H2O = FSP OPX CORD LIQtc q H2O

10): FSP OPX CORD LIQtc $=$ FSP OPX CORD LIQtc H2O

11): FSP OPX CORD LIQtc $=$ FSP CORD LIQtc

12): FSP CORD LIQtc $=$ FSP LIQtc

13): FSP LIQtc $=$ LIQtc

14): FSP OPX CORD LIQtc $q=$ FSP OPX CORD LIQtc $q \mathrm{H} 2 \mathrm{O}$

15): FSP OPX CORD LIQtc $\mathrm{q}=$ FSP OPX CORD LIQtc

16): FSP OPX CORD LIQtc $=$ FSP OPX LIQtc

17): FSP OPX LIQtc $=$ FSP LIQtc

18): (2)FSP OPX CORD LIQtc q H2O = (2)FSP OPX CORD LIQtc q

19): (2)FSP OPX CORD LIQtc $\mathrm{q}=$ FSP OPX CORD LIQtc $\mathrm{q}$

20): (2)FSP GARNET OPX BIO CORD q H2O = (2)FSP GARNET OPX CORD q H2O

21): (2)FSP GARNET OPX CORD q H2O = (2)FSP OPX CORD q H2O

22): FSP OPX CORD LIQtc $\mathrm{q}=$ FSP OPX LIQtc $\mathrm{q}$

23): FSP OPX LIQtc q = FSP OPX LIQtc

24): (2)FSP GARNET BIO CORD q H2O = (2)FSP GARNET OPX BIO CORD q H2O

25): (2)FSP GARNET OPX CORD q H2O = (2)FSP GARNET OPX CORD LIQtc q H2O

26): (2)FSP GARNET OPX CORD LIQtc q H2O = (2)FSP GARNET OPX CORD LIQtc $\mathrm{q}$

27): (2)FSP GARNET OPX CORD LIQtc $\mathrm{q}=(2)$ FSP OPX CORD LIQtc $\mathrm{q}$

28): (2)FSP GARNET BIO q H2O = (2)FSP GARNET OPX BIO q H2O

29): (2)FSP GARNET OPX BIO q H2O = (2)FSP GARNET OPX BIO CORD q H2O

30): (2)FSP GARNET OPX CORD LIQtc $\mathrm{q}=$ FSP GARNET OPX CORD LIQtc $\mathrm{q}$

31): FSP GARNET OPX CORD LIQtc $\mathrm{q}=$ FSP OPX CORD LIQtc $\mathrm{q}$

32): (2)FSP GARNET OPX LIQtc $\mathrm{q}=(2) F S P$ GARNET OPX CORD LIQtc $\mathrm{q}$

33): (2)FSP GARNET OPX LIQtc $\mathrm{q}=$ FSP GARNET OPX LIQtc $\mathrm{q}$

34): FSP GARNET OPX LIQtc $\mathrm{q}=$ FSP OPX LIQtc $\mathrm{q}$

35): (2)FSP OPX BIO CORD q H2O = (2)FSP OPX CORD q H2O

36): (2)FSP GARNET OPX BIO CORD q H2O = (2)FSP OPX BIO CORD q H2O

37): (2)FSP GARNET BIO q H2O = (2)FSP GARNET BIO CORD q H2O

38): FSP GARNET OPX LIQtc $\mathrm{q}=$ FSP GARNET OPX CORD LIQtc $\mathrm{q}$

39): FSP OPX CORD LIQtc trd H2O = FSP OPX CORD LIQtc q H2O

40): FSP CORD LIQtc $=$ FSP CORD LIQtc H2O

41): FSP LIQtc $=$ FSP LIQtc H2O

42): FSP LIQtc $\mathrm{H} 2 \mathrm{O}=\mathrm{LIQtc} \mathrm{H} 2 \mathrm{O}$

43): LIQtc $=$ LIQtc $\mathrm{H} 2 \mathrm{O}$

44): (2)FSP GARNET OPX CORD LIQtc q H2O = (2)FSP OPX CORD LIQtc q H2O

45): (2)FSP GARNET BIO q H2O = (2)FSP GARNET OPX BIO CORD q H2O

46): (2)FSP GARNET OPX BIO CORD q H2O = (2)FSP OPX CORD q H2O

47): (2)FSP OPX CORD LIQtc q H2O = (2)FSP OPX CORD LIQtc trd $\mathrm{H} 2 \mathrm{O}$

48): (2)FSP GARNET OPX CORD q H2O = (2)FSP OPX CORD LIQtc q H2O

49): (2)FSP OPX CORD LIQte q H2O = FSP OPX CORD LIQtc q 